
$\mathrm{XVI})$

\title{
Inca figurines from the Ethnologisches Museum in Berlin: an analytical study of some typical and atypical productions
}

Las estatuillas incas del Ethnologisches Museum de Berlín: un estudio analítico de algunas producciones típicas y atípicas

Les figurines Incas de l'Ethnologisches Museum de Berlin : une étude analytique de quelques productions typiques et atypiques

Maria Filomena Guerra, Manuela Fischer, Martin Radtke and Uwe Reinholz

\section{(2) OpenEdition}

Journals

Electronic version

URL: http://journals.openedition.org/bifea/8232

DOI: 10.4000/bifea.8232

ISSN: 2076-5827

\section{Publisher}

Institut Français d'Études Andines

\section{Printed version}

Date of publication: 1 April 2017

Number of pages: 221-252

ISSN: 0303-7495

\section{Electronic reference}

Maria Filomena Guerra, Manuela Fischer, Martin Radtke and Uwe Reinholz, «Inca figurines from the Ethnologisches Museum in Berlin: an analytical study of some typical and atypical productions », Bulletin de l'Institut français d'études andines [Online], 46 (1) | 2017, Online since 08 April 2017, connection on 05 November 2020. URL : http://journals.openedition.org/bifea/8232 ; DOI : https:// doi.org/10.4000/bifea.8232

\section{(c) $(1) \odot$}

Les contenus du Bulletin de l'Institut français d'études andines sont mis à disposition selon les termes de la licence Creative Commons Attribution - Pas d'Utilisation Commerciale - Pas de Modification 4.0 International. 


\title{
Inca figurines from the Ethnologisches Museum in Berlin: an analytical study of some typical and atypical productions
}

\author{
Maria Filomena Guerra* \\ Manuela Fischer ${ }^{* *}$ \\ Martin Radtke*** \\ Uwe Reinholz****
}

\begin{abstract}
Fourteen hollow and one cast anthropomorphic and zoomorphic figurines produced in Incan times for ritual offerings from the Ethnologisches Museum in Berlin were selected to investigate the technologies and alloys used for their fabrication with portable optical microscopy and non-destructive XRF elemental analysis. This group of gold and silver figurines includes typical specimens of the Inca production, such as the four silver figurines from the Island Coati in Lake Titicaca and the two gold figurines from Pachacamac, as well as specimens that are seldom present in collections, which makes them atypical. In addition to the tall figurines with atypical hair or standing pose, one bicolour figurine (half silver, half gold) and another with coloured inlays were included in this study for comparison. The large majority of the silver specimens are made from very high quality alloys and the gold figurines are made from alloys containing low copper contents and silver ranging from $30 \mathrm{wt} \%$ to $52 \mathrm{wt} \%$.
\end{abstract}

Keywords: silver, gold, figurine, Inca, alloy, atypical type

* CNRS, ArchAm-UMR 8096, Maison Archéologie \& Ethnologie, 21 allée de I'Université, 92023 Nanterre, France. E-mail: maria.guerra@cnrs.fr

** Ethnologisches Museum, Staatliche Museen zu Berlin, Preußischer Kulturbesitz, Germany. E-mail: m.fischer@smb.spk-berlin.de

*** Bundesanstalt für Materialforschung-und prüfung (BAM), Berlin, Germany. E-mail: martin.radtke@ bam.de

**** Bundesanstalt für Materialforschung-und prüfung (BAM), Berlin, Germany. E-mail: uwe.reinholz@ bam.de 


\title{
Las estatuillas incas del Ethnologisches Museum de Berlín: un estudio analítico de algunas producciones típicas y atípicas
}

\begin{abstract}
Resumen
Catorce estatuillas antropomorfas y zoomorfas laminadas y una vaciada, pertenecientes a la colección del Ethnologisches Museum de Berlín, producidas en el tiempo de los incas para ofrendas rituales, fueron seleccionadas para abordar las tecnologías y aleaciones empleadas en su manufactura a través de las técnicas portables de microscopía óptica y elemental no destructiva FRX. Este grupo de estatuillas, en oro y plata, abarca ejemplares típicos de la producción Inca, como las cuatro figuras en plata provenientes de la Isla Coati en el Lago Titicaca y las dos en oro provenientes de Pachacamac, así como ejemplares cuyos tipos son raros en las colecciones, lo que las convierte en atípicas. Además de las grandes figuras con pelo y postura atípicos, fueron también incluidas en este estudio la estatuilla bicolor (mitad plata y mitad oro) y la figurina con incrustaciones coloridas para comparación. La gran mayoría de las figurinas de plata fueron fabricadas con aleaciones de muy buena calidad y las figurinas en oro con aleaciones conteniendo bajas cantidades de cobre y concentraciones de plata entre $30 \%$ y $52 \%$.
\end{abstract}

Palabras clave: plata, oro, estatuilla, inca, aleaciones, tipo atípico

\section{Les figurines Incas de l'Ethnologisches Museum de Berlin : une étude analytique de quelques productions typiques et atypiques}

\section{Résumé}

Quatorze figurines anthropomorphes et zoomorphes creuses et une en fonte pleine, appartenant à la collection du Ethnologisches Museum de Berlin, produites aux temps des Incas pour des offrandes rituelles, ont été sélectionnées pour approcher les technologies et alliages employés dans leur fabrication au moyen des méthodes portables de microscopie optique et d'analyse élémentaire nondestructive FRX. Ce groupe de figurines, en or et en argent, inclut des spécimens typiques de la production Inca, dont les quatre figurines en argent provenant de I'lle Coati sur le Lac Titicaca et les deux en or provenant de Pachacamac, ainsi que des spécimens se trouvant rarement présents dans les collections et qui s'avèrent ainsi atypiques. En plus de figurines de grande taille avec des cheveux et des positions debout atypiques, une figurine bicouleur (moitié argent, moitié or) et une autre avec des incrustations colorées ont été intégrées à cette étude pour comparaison. La grande majorité des figurines en argent est produite à partir d'alliages de très bonne qualité et les figurines en or sont produites avec un alliage contenant de faibles teneurs en cuivre et une concentration en argent variant entre $30 \%$ et $52 \%$.

Mots-clés : argent, or, figurine, inca, alliages, type atypique

\section{INTRODUCTION}

Small anthropomorphic (male and female) and zoomorphic figurines made of gold, silver, or spondylus, were produced in Incan times for ritual offerings (Besom, 2013: chapt. 7). They were offered to huacas (sacred places) or used during the Capacocha ceremony (Benson, 2001); several of them were found in mountaintop shrines (Reinhard \& Ceruti, 2005) dressed with textiles, feathers and 
other materials like silver and gold fasteners, called tupus (Vetter, 2007; Fernández Murillo, 2015; Vetter \& Guerra, in this volume), others were nevertheless found undressed, with or without metallic tupus.

The variety of the finds raised questions about the possible deterioration of the organic materials, which could explain the absence of garments in certain offerings and the fact that the large majority of the anthropomorphic figurines that survived are nowadays undressed. However, among the six figurines in silver and in gold from the cacique's tomb found in Paucartambo, district of Cusco, discussed in this volume by Sierra Palomino \& Guerra, only two silver female figurines were found dressed. One of them was contained in a wood box adorned with two tupus. The other dressed figurine had no associated tupus and the other five miniatures tupus in silver from the find had no figurines associated. No other organic materials that could belong to their garments were reported.

The most interesting situation however concerns the offerings found underwater in Lake Titicaca that contained undressed gold and silver figurines and organic materials. One closed andeside box contained one undressed figurine, another box contained three gold tupus but no figurines (Reinhard, 1992; Dransart, 2000), and a third box contained one silver lama together with well-conserved fish bones (Reinhard, 1992: 124). These finds suggest the fact that the objects were necessarily not offered together and that under favourable conditions organic materials could be preserved, but without further information, it is difficult to draw any further conclusions.

In spite of the absence of large studies on the anthropomorphic and zoomorphic Incan gold and silver figurines' finds, typology, iconography and metallurgy, these objects seem to correspond, in general, to a sort of "traditional Inca canon".

The proportions and standing poses of the anthropomorphic and zoomorphic figurines are in general rather standardised, with their gender represented as well as the attributes related to their high status. These attributes depend on their gender: male figurines have the llautu (or headband) around their heads, and although their earpools are regularly absent, they have elongated pierced ears; female figurines have long hair arranged in two braids fastened on their backs. In general, both have the prominence corresponding to coca leaves chewing and the arms bent over their chests.

In spite of having quite standardised proportions, the stature of the anthropomorphic and zoomorphic figurines is quite variable, as demonstrate for instance by Baessler (1906: pl. 37, figs. 541-544) for the four anthropomorphic figurines attributed to Pachacamac. Dransart, who compiles data on several anthropomorphic figurines (Dransart, 2000), concludes that they are in general 5 to $15 \mathrm{~cm}$ tall1. The largest group of figurines belongs to the Llullaillaco shrines, their stature range according to Mignone (2015) from 3 to $15 \mathrm{~cm}$. Larger figurines are however known, like

1 P. Dransart dresses a list of the high altitude mountain shrines with surviving metallic figurines with detail on their dimensions (Dransart, 1995: 47-49). 
those from Pachacamac cited by Baessler (1906: pl. 37, figs 541-543) that are 15.2 to $24.3 \mathrm{~cm}$ tall. Additional larger silver figurines (20 to $24 \mathrm{~cm}$ ) are known: a male figurine from the site of Choquepujio (Gibaja Oviedo et al., 2014); the Dumbarton Oaks silver male figurine (Rowe, 1996: 307), similar to a figurine kept at National Museums Scotland (Idiens, 1971; Troalen \& Guerra, in this volume) and to others kept in the Museo de América in Madrid (Cuesta Domingo \& Rovira Lloréns, 1982; Rovira Lloréns \& Gómez Ramos, 1995; Rovira, in this volume); a silver male figurine from the musée du quai Branly - Jacques Chirac in Paris (Núnez-Regueiro et al., in this volume); and finally a tall bicolour female figurine (nowadays incomplete) from the site of Chimur in Paucartambo (Sierra Palomino \& Guerra, in this volume). In contrast, one silver female figurine found in the shrine of Nevado Mercenario in Argentina is only $3 \mathrm{~cm}$ tall (Dransart, 1995). Small gold figurines are nowadays held by the Museo Inka and the Dirección Desconcentrada de Cultura in Cusco (fig. 1). They were found in sites situated in the region of Cusco, such as Qorikancha and Lucre (Valencia, 1981).

Sites like Chimur in Paucartambo (Sierra Palomino \& Guerra, in this volume) and Choquepujio (Gibaja Oviedo et al., 2014) contained figurines with varied dimensions. Among the most interesting cases, are the figurines from La Plata Island (coast of Ecuador). The set of anthropomorphic figurines of varied dimensions found together with miniature tupus and miniature vessel could be linked to a marriage ceremony in Cusco; when arranged by size and material of production they correspond to the social Inca organization, with the three ranked social categories (McEwan, 2015: 280-283).

The gold and silver figurines were either produced hollow, by hammering foils that were then cut, rolled and hard-soldered (the un-soldered figurine of fig. 2 illustrates their construction2) or sometimes solid, by pouring the metal into moulds. Even if the hollow figurines seem to be more frequent in museum collections, nowadays it is difficult to know the original ratio hollow/solid. Little information has been published on their production techniques and an extensive list of the specimens is still missing for some collections. It is obviously even harder to identify any relation between the metallurgical technique employed (hammering or casting) and the chronology of their production or yet the areas or workshops where they could have been produced.

Andean metalwork, in particular from the north of Peru, was produced with surface enhancement (for example, Lechtman, 1973; 2014; Bray, 1993). Nevertheless, few specimens of the Incan figurines were gilded or silvered or even enhanced by application of any surface treatment ${ }^{3}$. According to the very small amount

2 I. Schuler-Schömig (1981: 22-24) describes the construction of these figurines: one llama made with thirteen hammered and rolled foils and one female made with nine foils, while J. H. Rowe (1996: $305,308)$ published some X-ray radiographies showing the mounting of female and male figurines.

3 The zoomorphic figurine (accession number ME I 126) from the collection of the Inka Museum in Cusco is cast in copper alloy and was then silver-plated. 
Inca figurines from the Ethnologisches Museum: an analytical study of some typical and atypical productions

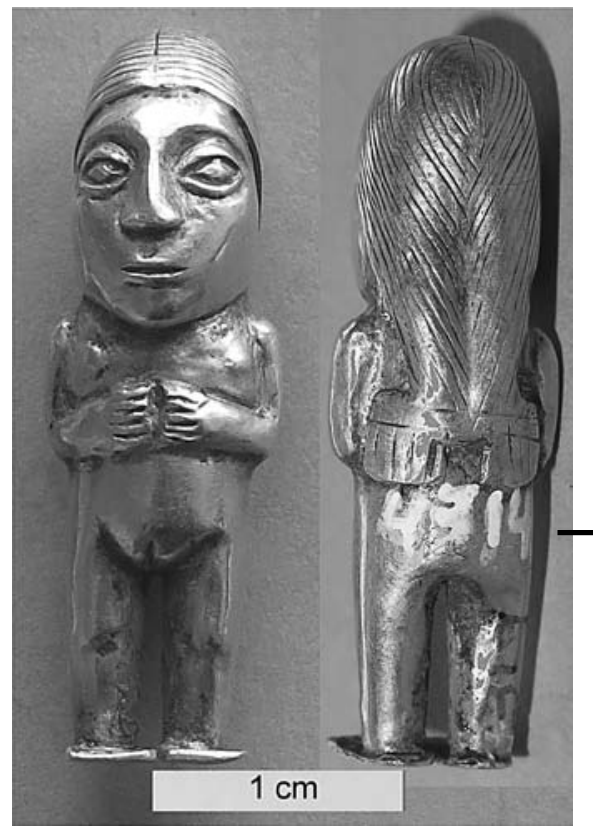

Figure 1 - Hollow gold figurine found in the archaeological excavations lead by Dr. Luis Barreda Murillo in Qorikancha (Valencia, 1981), Cusco, nowadays exhibited in the Inka Museum, San Antonio Abad National University of Cusco

(C) M. F. Guerra
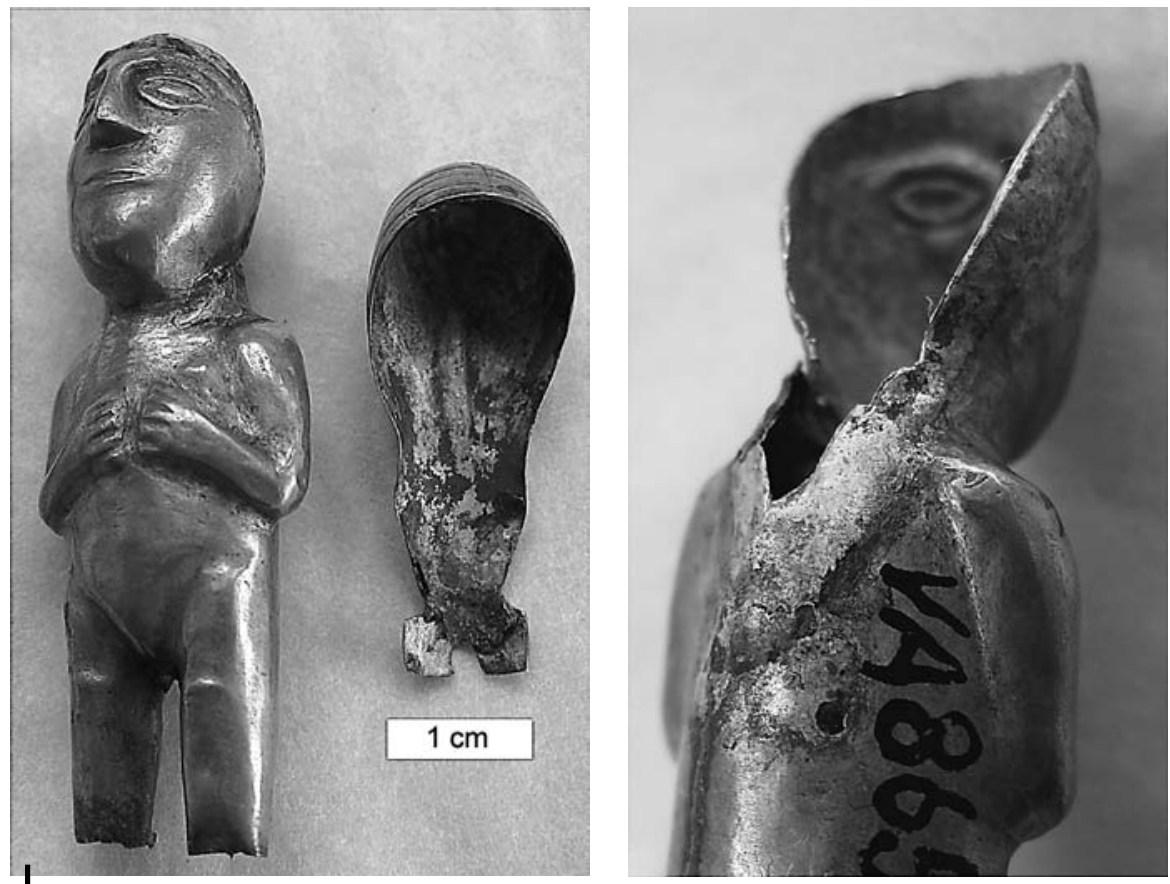

Figure 2 - Hollow silver female figurine V A 8653 from the collection of the Ethnologische Museum. The two foils that form the body and the hair of the figurine are nowadays unsoldered

(C) M. F. Guerra 
of analytical data available ${ }^{4}$, the colour of the alloys were regularly achieved for these figurines by the skilled choice of the concentrations of each of the metals component of the alloys.

As discussed by Núnez-Regueiro et al. and Vetter \& Guerra in this volume, it is nowadays difficult to understand certain figurines. By their atypical types and iconographic details (which it is sometimes hard to imagine being outlined before the Spanish conquest) they appear to deviate from the regular Incan production and could represent the production of the colonial period either by the locals for their rituals or by the Spanish under the influence of the Incan art.

The rich collection of the Ethnologisches Museum in Berlin includes very typical gold and silver figurines of the Incan production as well as specimens whose typology, size and materials employed are hardly ever found in other collections and for this reason are considered here as atypical. This study is a first investigation using mobile optical microscopy and non-destructive elemental analysis of the technologies and alloys employed in the fabrication of a selection of typical and atypical gold and silver figurines in order to search for possible differentiation criteria.

\section{SELECTED FIGURINES FROM THE COLLECTION OF THE ETHNOLOGISCHES MUSEUM}

The Inca collection at the Ethnologisches Museum in Berlin is quite important due to the acquisition of the famous collection of Doña María Ana Centeno de Romainville (1816-1874) in Cuzco (Fischer, 2015). The collection of more than 1100 objects mainly from Cuzco was acquired from her heirs in 1888 by the then Königliches Museum für Völkerkunde in Berlin. The other important collection, which has approximately 900 objects from the Late Horizon, is the one the merchant Wilhelm Gretzer (1847-1926) gathered in his 30 years stay in Peru. The nearly 40,000 objects from the whole collection were purchased between in 1899 and in 1907. The only scientific expedition to the Tawantisuyu in 1892-1895 was assigned to Max Uhle (1856-1944). As his research was focused on the meridional frontier of the Inca empire, his collection mainly stems from Northwest Argentina and Bolivia (380 out of a total of 4640 objects are Inca).

Notable among the silver figurines in the collection of the Ethnologisches Museum, are the group of three female figurines (one complete, V A 61521, and two with missing feet, V A 61520 and V A 61522) and one male llama (with missing feet, V A 61518) from the Island of the Moon (Isla Coati) in Lake Titicaca (fig. 3). Eduard Seler bought these objects in 1910.

4 Bárcena (2004) for the Cerro Aconcagua mummy in Argentina, Oberhauser \& Fuhrmann (19571959) for the El Plomo mummy in Chile, Rovira Lloréns \& Gómez Ramos (1995) for the collection of Museo de América in Madrid, and those published in this number of the Bulletin de l'Institut Français d'Études Andines by Sierra Palomino \& Guerra for the site of Chimur in Paucartambo, by Vetter \& Guerra for the collections of the Inka Museum and the Gold Museum in Peru, by Troalen \& Guerra for the silver figurine from National Museums Scotland, and by Núnez-Regueiro et al. for the collection of the musée du quai Branly - Jacques Chirac in Paris. 

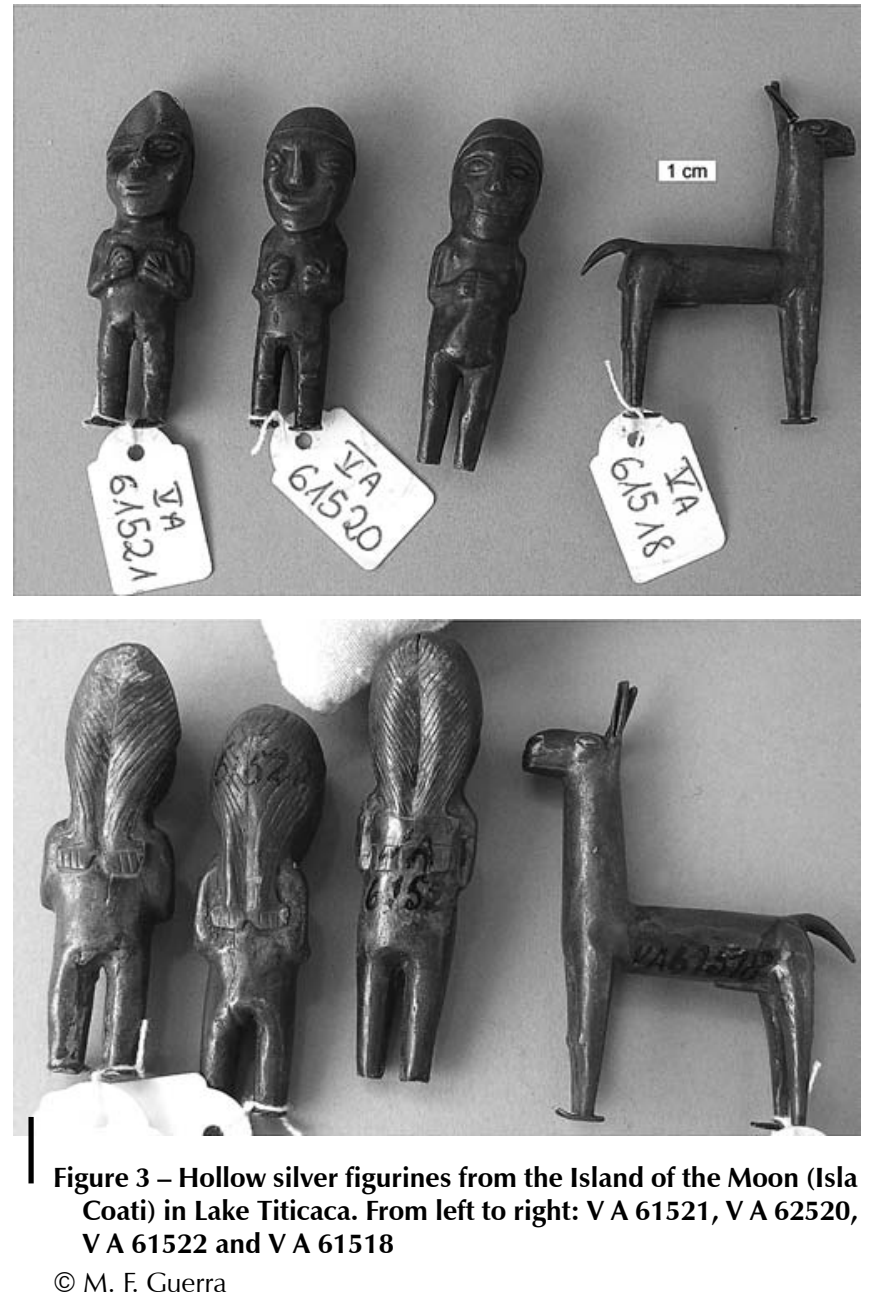

These hollow figurines are typical of the traditional Inca production and constructed as expected by soldering separate silver foils, as described for example by I. von Schuler-Schömig (1981): the hair, the body and the feet for the women and the body, the legs, the tail, the genital, the feet, the ears and the head for the llama. Despite the fact that the attributes and standing pose observed are those expected for the female figurines and that their dimensions are similar, several details differentiate these three specimens. Their hands are not in the same position, the breast is only well represented on figurine V A 65120, and their expressions are different (the form of their mouths, eyes, chins and cheeks). Their knees are also differently drawn and on their back, the foils that represent their braids are only precisely cut in V A 65122. The braids of figurine V A 65122 are fastened in a different way and her hair is more carefully chased. All the distinctions described can be attributed to a manufacture by different silversmiths; the one who made 
figurine V A 65122 was certainly more skilled. A skilled silversmith also made the Ilama; as the animal's expression and all the anatomic details were carefully obtained by means of chasing and in repoussé.

Two other finely made hollow male silver figurines from the Ethnologisches Museum collection were also selected for this study (fig. 4): V A 31761 (one foot is missing) and V A 45830 (the genital is missing), an acquisition from the Wilhelm Gretzer's collection in 1907. As in the case of the female figurines previously described, these male figurines, produced in the regular Inca tradition, have the same standing pose and attributes, but a different expression. Figurine V A 31761 has a round face and $V A 45830$ an aquiline profile. Figure 4 shows the detail of V A 31761 where the prominence of the coca leaves chewing is clearly visible as well as the prominences of the wrists. Their arms also exhibit different positions.
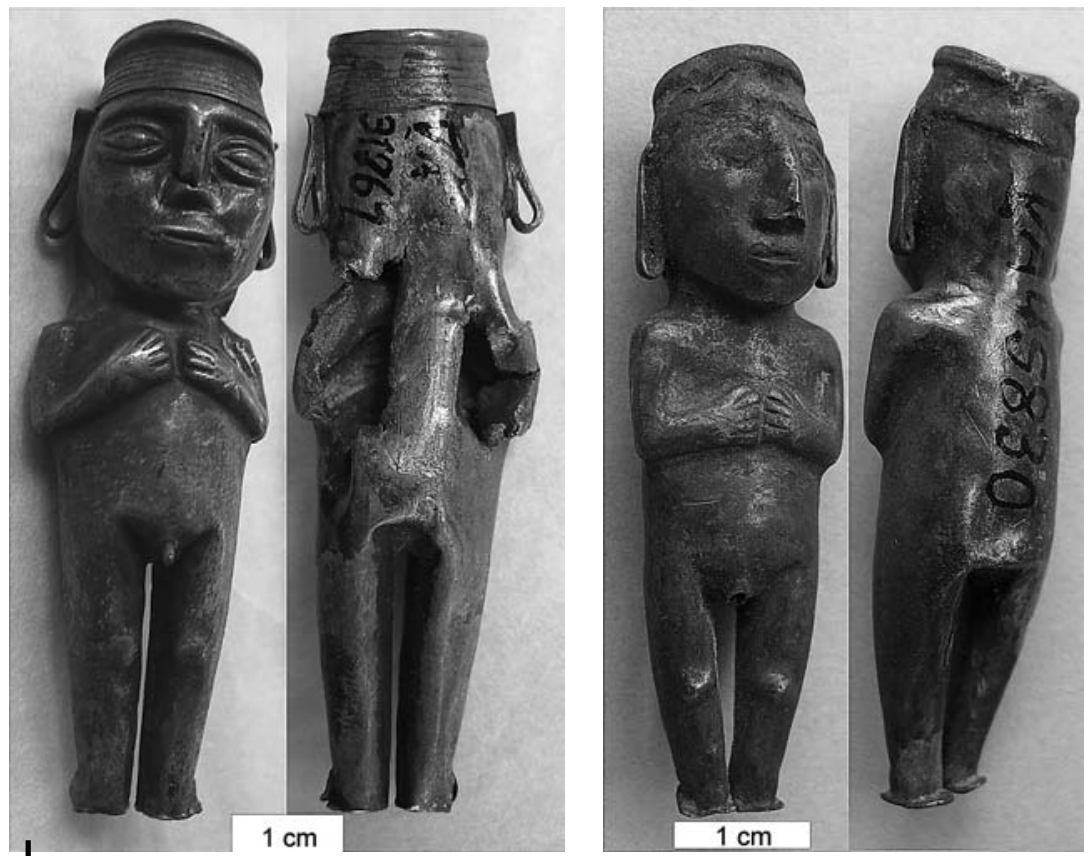

Figure 4 - Hollow silver figurines V A 31761 (on the left) and V A 45830 (on the right) (C) M. F. Guerra

Among the other objects in the Ethnologisches Museum collection, two hollow female figurines stand out by their size: the silver specimen V A 28917 from the Arthur Baessler's collection, about $23 \mathrm{~cm}$ tall, and the gold specimen V A 8652 acquired in 1889 from Doña María Ana Centeno's collection, about $14.7 \mathrm{~cm}$ tall, with a weight of $54.87 \mathrm{~g}$.

Although they are produced with the usual Inca technology, these two figurines (fig. 5) have several particularities. The silver figurine V A 28917 is finely made, the carefully chassed hair is shown in detail in figure $6 \mathrm{a}$, the braids are also well-chased 


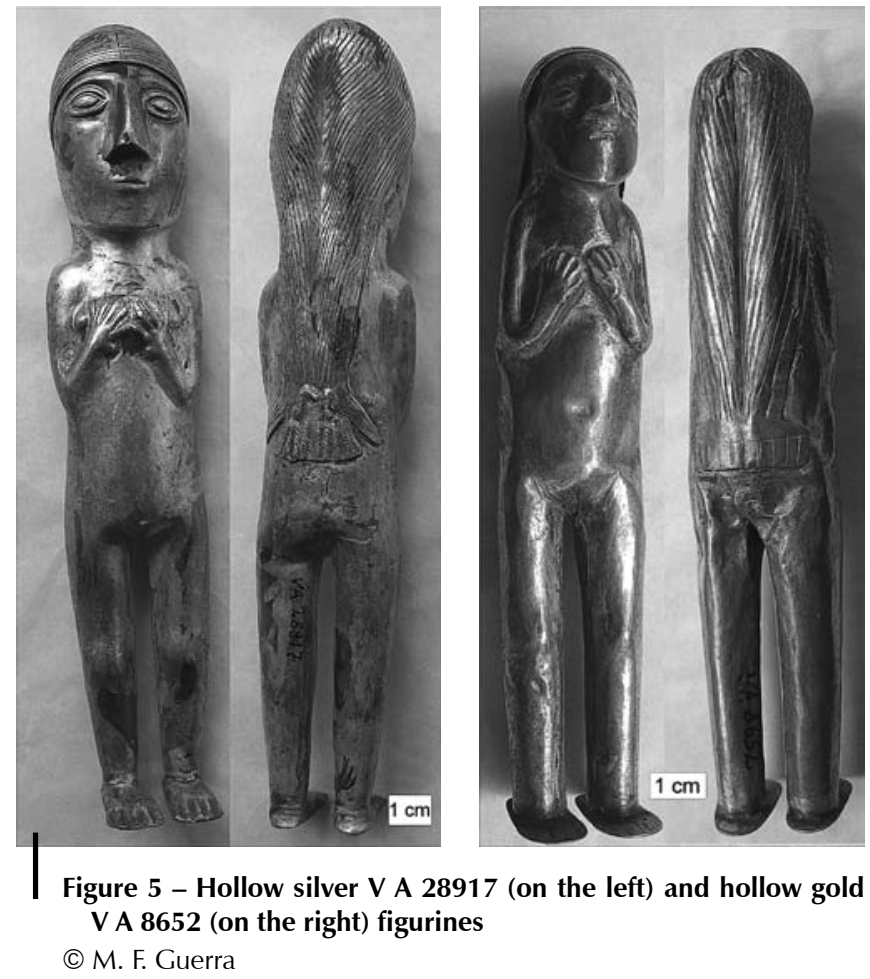

and the hair is fastened in an atypical way, as shown in figure $6 \mathrm{~b}$. The hands, laying on the in repoussé breasts, have outlined wrists and, like her feet, chased nails, a detail hardly ever represented elsewhere. In addition and in contrast to what was observed for the previously described figurines, the feet are made with two hardsoldered foils to create a volume and to well outline the toes (fig. 6c).

The gold figurine V A 8652 with a rounded belly and navel is not a skilled production and has a different standing pose, as if she was looking up. The very prominent nose is made over one chased line, the mouth in its simplest expression that embellishes the very pointed chin. The feet are almost round cut foils, barely chased to suggest the toes (fig. 7a). The hair is also sketchily chased on the gold foil (fig. 7b).

The Ethnologisches Museum collection lone bicolour figurine V A 31764, which has inlaid eyes, the upper part in gold and the lower part in silver, was also selected for this study (fig. 8). This hollow female figurine of about $13.8 \mathrm{~cm}$ high was acquired from the Wilhelm Gretzer's collection in 1907. The proportions, standing pose, and attributes of this figurine are those expected for a regular Inca production. The hair is chased and the two braids are fastened on the back; figure 9a illustrates the sequence of the chased lines: the vertical lines are drawn after the horizontal lines. The regular soldering seams can be seen in both parts of the figurine. Figure $9 \mathrm{~b}$ shows thick silver join at the legs that could correspond at least partially to a repair. 

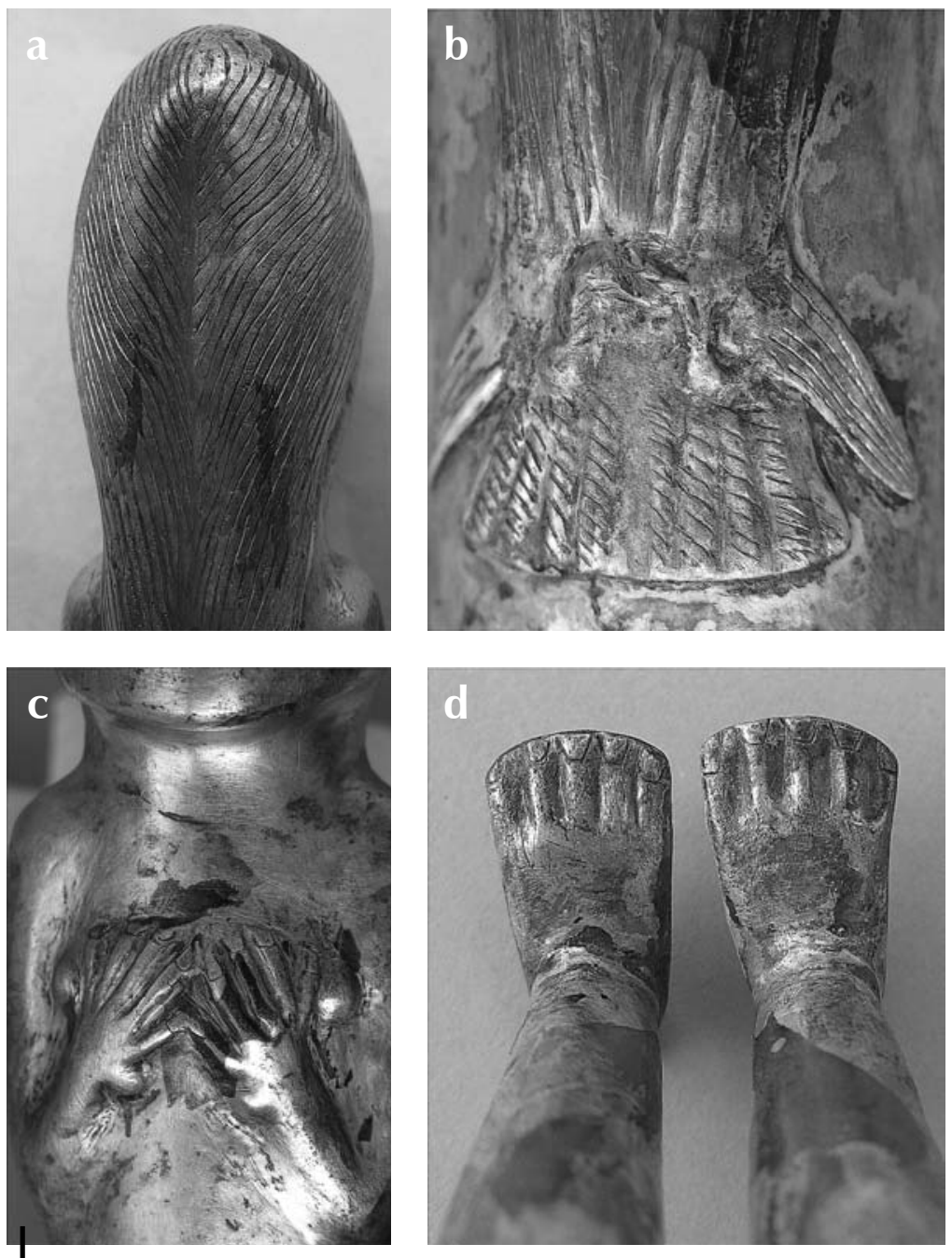

Figure 6 - Details of the hollow silver figurine V A 28917: (a) the chased hair, (b) the braids fastener; and the (c) hands and (d) feet with drawn nails

(C) M. F. Guerra 

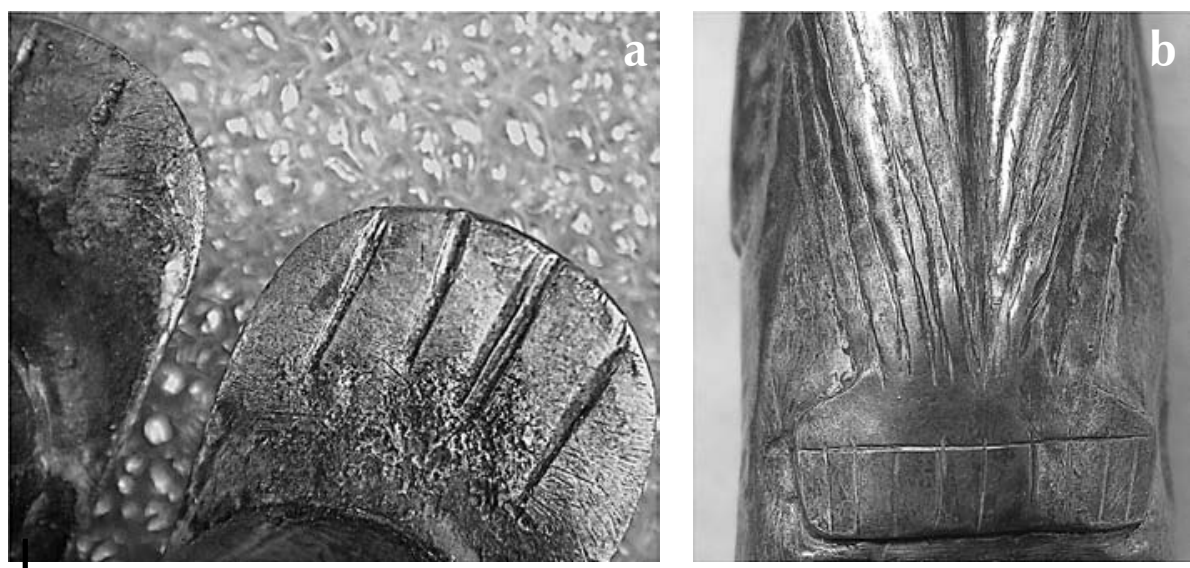

Figure 7 - Details of the hollow gold figurine V A 8652: (a) chased foot and (b) the hair and braids fastener

(C) M. F. Guerra
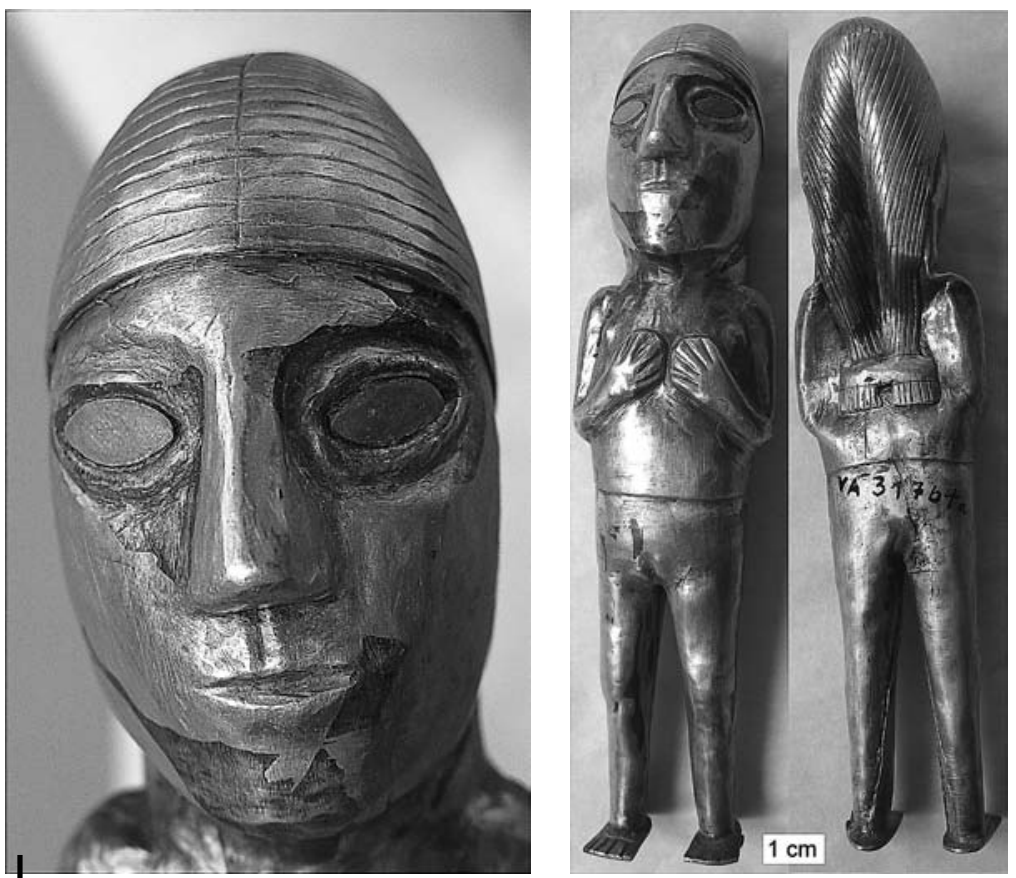

Figure 8 - Hollow silver and gold figurine V A 31764, which has inlaid eyes of different colour (which is considered to be original, not an effect of degradation by environmental exposure)

(c) M. F. Guerra 

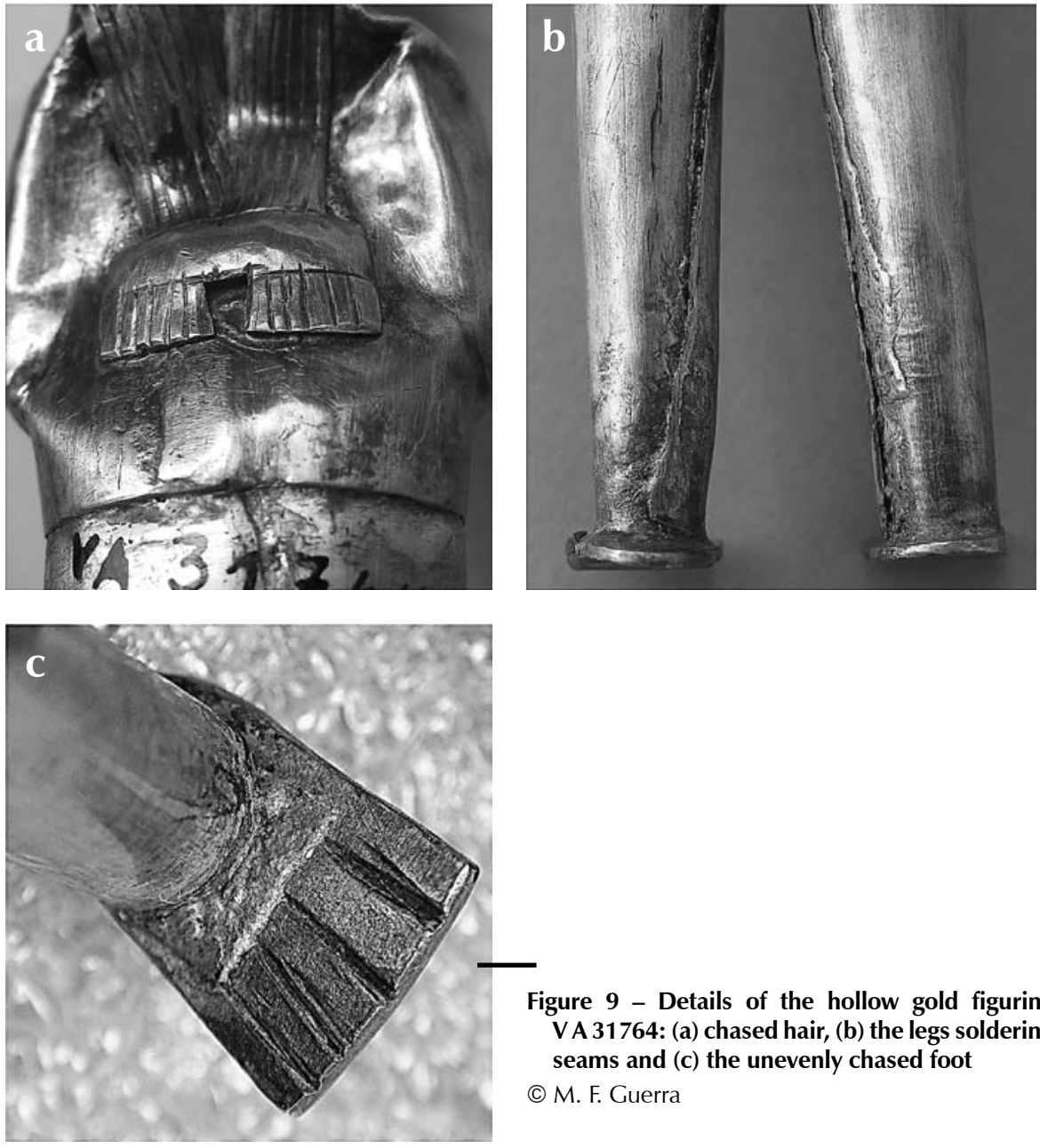

Figure 9 - Details of the hollow gold figurine VA 31764: (a) chased hair, (b) the legs soldering seams and (c) the unevenly chased foot

(C) M. F. Guerra

The two parts of the figurine are soldered after fitting the silver part into the gold part ${ }^{5}$, as shown in figure 10 . The whitish hard-solder on the figurine's front (fig. 10a) could correspond to a repair. Another repair can be seen under the left arm. The soldering and the tool marks of the gold foil cut can be seen on the back of the figurine (figs. $10 \mathrm{~b}$ and 10c).

Five hollow gold traditional figurines, two male zoomorphic from the Wilhelm Gretzer's collection bought by Arthur Baessler in 1899 (V A 28356 and V A 31767), two male zoomorphic (V A 28909, V A 28910) that Arthur Baessler offered to

5 The bicolour figurine from the cacique's tomb in Paucartambo is not soldered; the upper silver part of this figurine only fits into its lower copper part (Sierra Palomino \& Guerra, in this volume). For both figurines, the noblest metal is used in the upper part of the body. 
Inca figurines from the Ethnologisches Museum: an analytical study of some typical and atypical productions
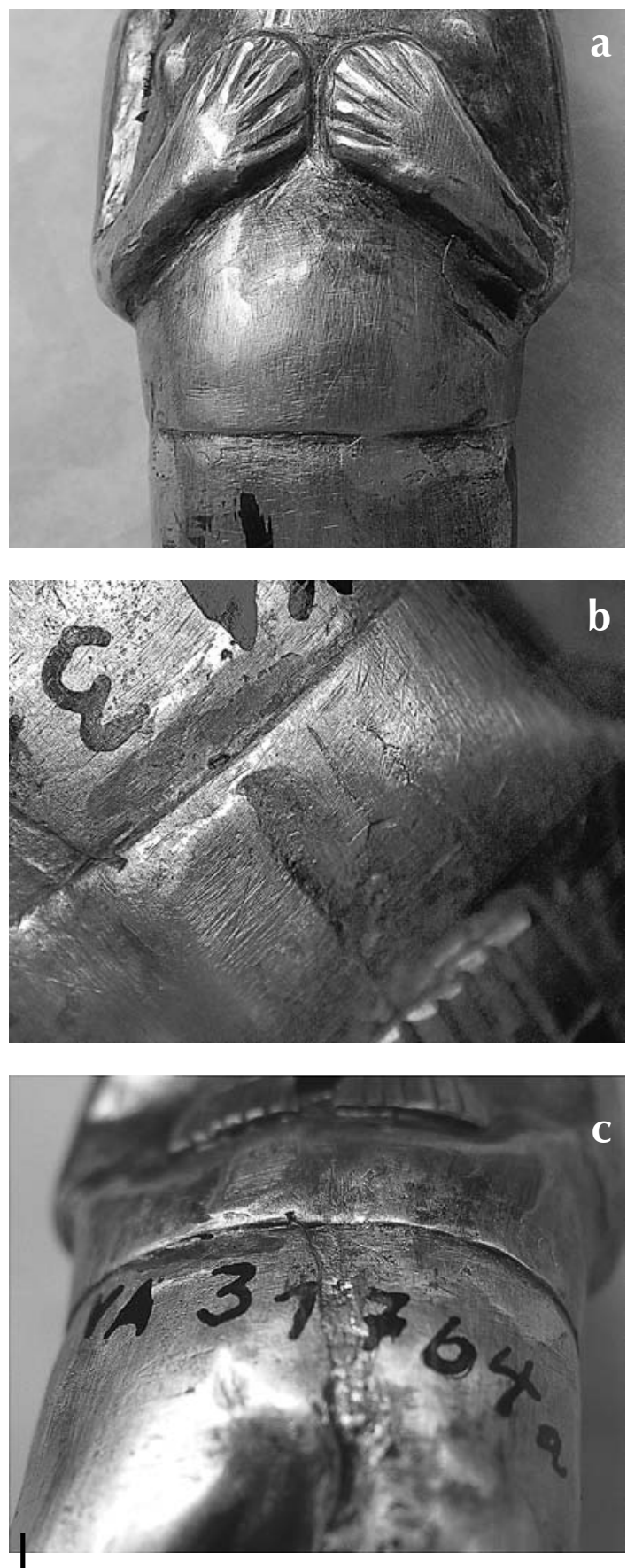

Figure 10 - Details of the joining of the hollow gold figurine V A 31764: (a) front, (b) and (c) back

(C) M. F. Guerra 
the Museum in 1905 (fig. 11), and one male anthropomorphic (V A 28887, fig. 12), were selected for comparison in this study with the gold part of figurine V A 31764. Figurines V A 28356 and V A 28887 are incomplete and attributed to the site of Pachacamac. All the five figurines are constructed as expected and have feet made from cut and hammered foils. The four zoomorphic figurines have different proportions for their heads, necks, bodies and legs, and their postures are not exactly the same, in particular the legs. The male anthropomorphic figurine has regular proportions, attributes and standing pose, but has quite a prominent nose and a pointed chin. The arms are nowadays soldered to the body, which certainly resulted from a modern repair.
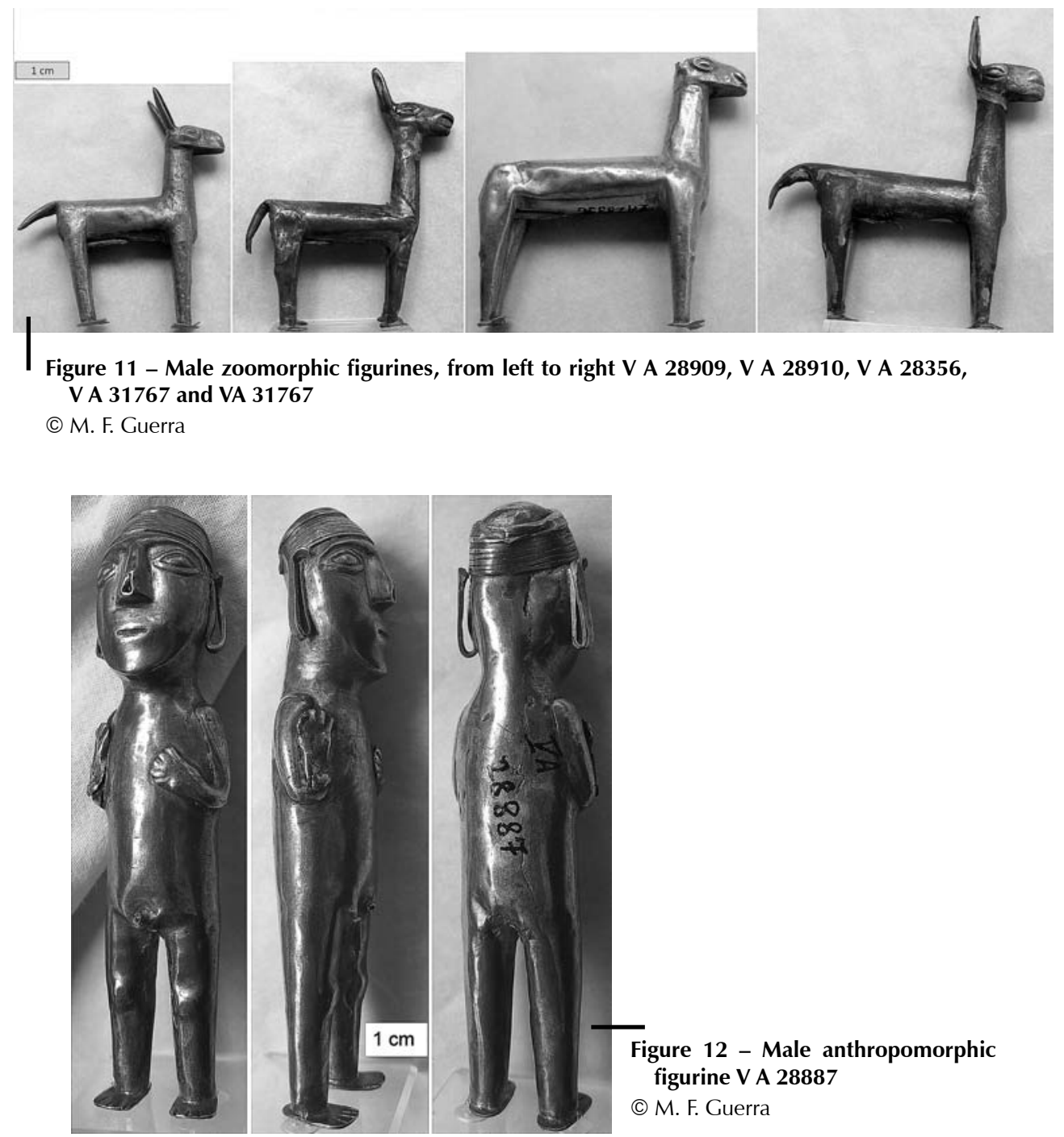

Figure 12 - Male anthropomorphic figurine V A 28887

(C) M. F. Guerra 
The last specimen selected for this study is the male silver figurine $14.7 \mathrm{~cm}$ tall V A 28915, from the Arthur Baessler's collection (fig. 13). In contrast to all the other figurines previously described, V A 28915 was cast and was decorated with inlays of different colours. The rounded cavity on the figurine's back seems to be caused by a casting defect (probably shrinkage). The proportions, attributes and standing pose of this figurine are those expected for this type of production. Several archaeological sites have delivered cast figurines, like Chimur in Paucartambo (Sierra Palomino \& Guerra, in this volume), and the site of Choquepujio. The latter delivered one male figurine with a headband made from metal and spondylus (Gibaja Oviedo et al., 2014). Very few cast figurines with coloured insets are known and to date none has been found in capacocha shrines6. Two specimens very similar to V A 28915, attributed to Pachacamac by Cuesta Domingo \& Rovira Lloréns (1982), belong to the Museo de América (accession number 7025 and 7043, one male and one female, respectively). Two silver cast female figurines with inlays were published by Lapiner (1976: 315). One belongs to a private collection and another to the National Museum of Denmark.

Figure 14 shows the seams of figurine V A 28915 where the coloured materials were included, but nowadays sometimes empty. Figure 15a shows the empty seam that crosses the figurine's nose. On the left side of the figurine's face, close to the ear, some residues of the original inlay can still be found. Some lines are golden and blackish, as shown in figure 16, suggesting the application of gilding and silver compounds (sulphides or chlorides). Another unexpected detail for an Incan production is the peculiar form of the base of the feet that looks like heels, or could correspond to an original "support".

\section{COMPOSITION OF THE ALLOYS}

The fifteen figurines were studied in-situ with portable equipment (Guerra, 2008; Guerra \& Tissot, 2016). The construction details were observed under a digital microscope Pro Celestron with a 5MP sensor. The composition of the alloys was determined with a Bruker Tracer III SD7 portable XRF spectrometer with an integrated camera. The objects were positioned on the fixed spectrometer table to ensure constant measurement conditions. However, due to their irregular shapes and the spot size of $3 \times 4 \mathrm{~mm}$, only approximately constant measurement conditions could be reached. The measurement time was 100 s per point. The surfaces were not prepared before analysis. Depending on the object size and construction, two to four measurements were carried out.

To determine the accuracy of the experimental results, a set of five gold and three silver standards (see table 1 ) were analysed with the same experimental conditions

6 Plate 44 of Rivero \& Tschudi (1851) provides the representation of one of these figurines together with a bicolour specimen.

7 X-ray tube with Rh target, voltage $40 \mathrm{kV} ; 10 \mathrm{~mm}^{2}$ XFlash ${ }^{\circledR}$ SDD detector Peltier cooled with typical resolution of $145 \mathrm{eV}$ at $100000 \mathrm{cps}$. 

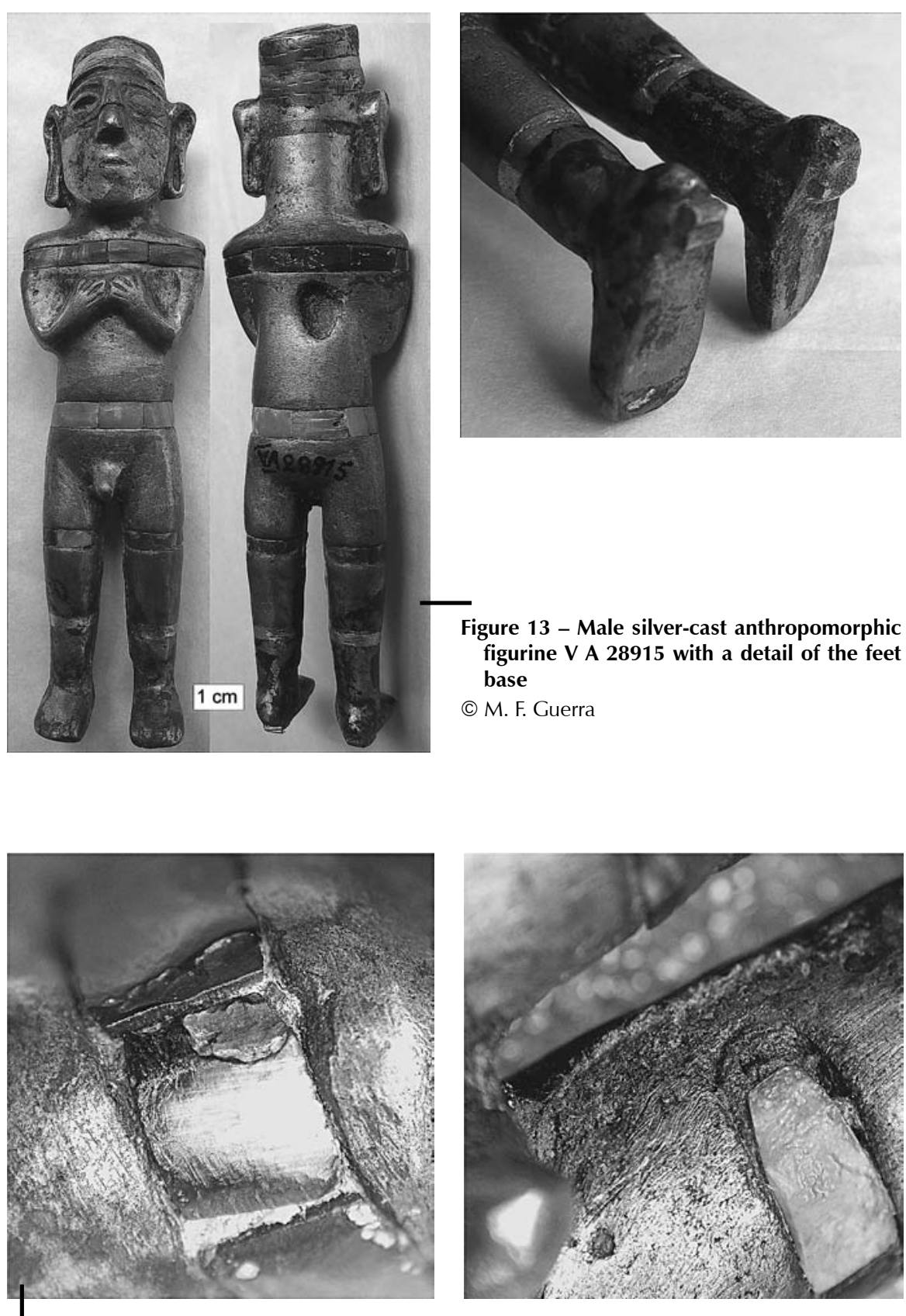

Figure 14 - Details of the inlays of the silver-cast figurine V A 28915

(C) M. F. Guerra 

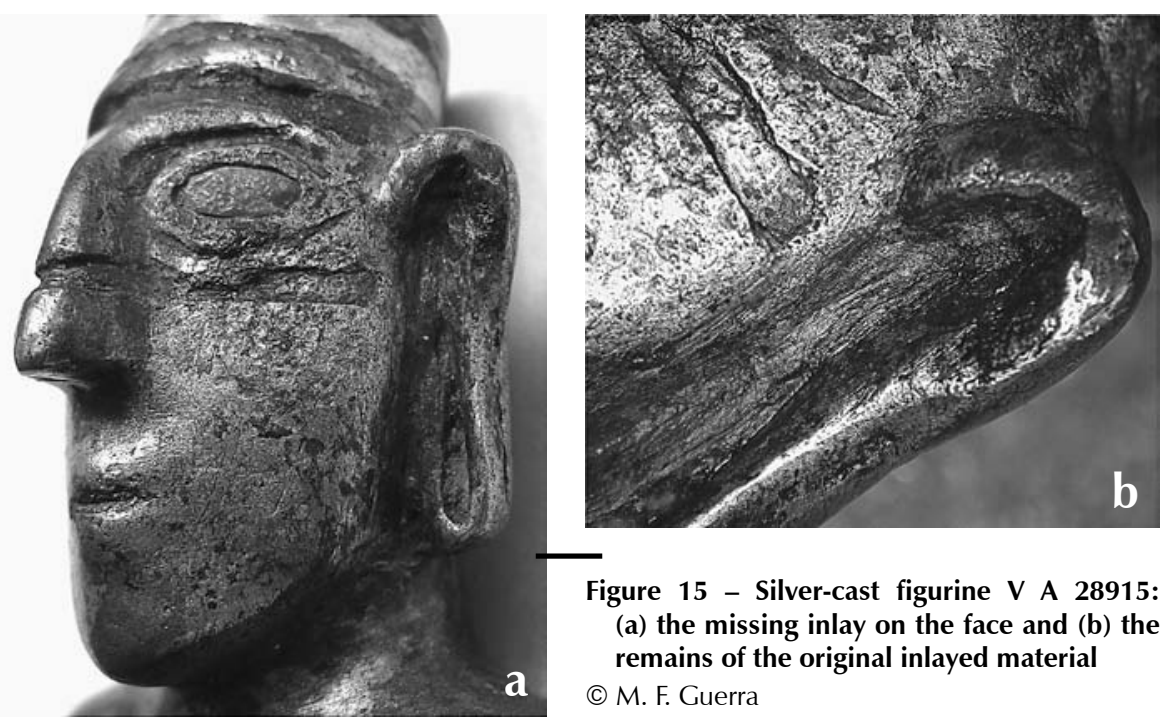

Figure 15 - Silver-cast figurine V A 28915: (a) the missing inlay on the face and (b) the remains of the original inlayed material

(C) M. F. Guerra
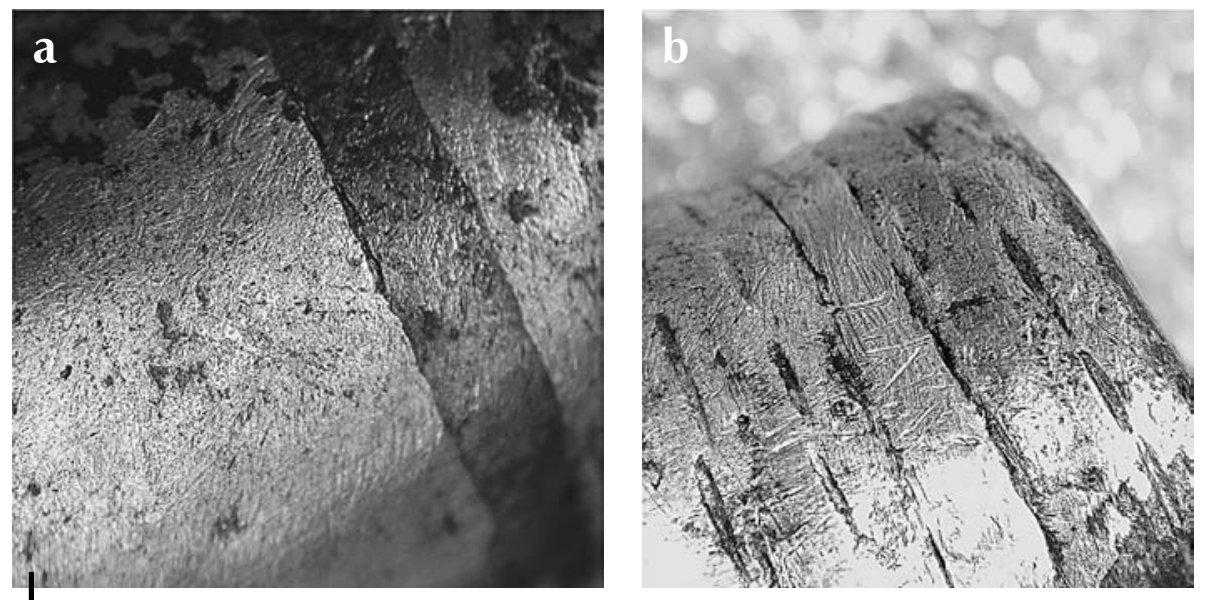

Figure 16 - The silvery and golden inlayed materials of silver-cast figurine V A 28915: (a) on the leg and (b) on the head

(c) M. F. Guerra 
Table 1 - Comparison of the certified values and the data obtained by XRF at the routine experimental conditions for a group of silver standards (from Goodfellow) and gold standards (697 from Comptoir Lyon-Alemand, Louyot et $\mathrm{Cie}$ and the others produced by the European project Authentico, see Guerra, 2009), CV- certified values and MV-measured values

\begin{tabular}{|c|c|c|c|c|}
\hline Reference & & $\mathrm{Au}$ & Ag & $\mathrm{Cu}$ \\
\hline \multirow[t]{2}{*}{ CLA 697} & $C V$ & 76 & 17 & 7 \\
\hline & MV & 76.8 & 16.4 & 6.9 \\
\hline \multirow[t]{2}{*}{ la1 } & $C V$ & 92.6 & 6.4 & 1 \\
\hline & MV & 92.6 & 6.4 & 1.1 \\
\hline \multirow[t]{2}{*}{ la2 } & $C V$ & 74.6 & 22.6 & 2.8 \\
\hline & MV & 74.1 & 22.5 & 3.6 \\
\hline \multirow[t]{2}{*}{ le1 } & $C V$ & 50.8 & 49.2 & 0.02 \\
\hline & MV & 51.1 & 49.2 & 0.1 \\
\hline \multirow[t]{2}{*}{ le2 } & $C V$ & 56 & 43.5 & 0.5 \\
\hline & MV & 56.0 & 43.9 & 0.6 \\
\hline \multirow[t]{2}{*}{ Goodfellow 1} & $C V$ & & 71 & 29 \\
\hline & MV & & 70.2 & 29.7 \\
\hline \multirow[t]{2}{*}{ Goodfellow 2} & $C V$ & & 92.5 & 7.5 \\
\hline & MV & & 92.4 & 7.7 \\
\hline \multirow[t]{2}{*}{ Goodfellow 3} & $C V$ & & 80 & 20 \\
\hline & MV & & 80.7 & 20.0 \\
\hline
\end{tabular}

as the figurines. The quantification was based on these standards. The relations between the number of counts and the elemental concentrations were calculated with Eureqa (Schmidt \& Lipson, 2009), an artificial intelligence powered modelling engine. To avoid overfitting, data were split in two groups, one to train the model, the other to validate its accuracy. The raw counts extracted with AXIL software from the XRF spectra were used as input for Eureqa. Figure 17 shows for silver the good agreement for predicted versus the observed concentrations. Table 1 shows as well the likewise good agreement for gold and copper concentrations. With the exception of measurements near the detection limits, the difference between measured and certified values is less than $1 \%$ absolute. It should be mentioned that this demonstrates the potential of the model found by Eureqa for ideal specimens. Due to geometry effects and potential surface contaminations, less accuracy is expected for real samples.

Elements not present in the standards (tin, lead and zinc) were also calculated. The rule of proportion in relation to the nearest certified element was applied (in our case gold for lead, copper for zinc and silver for tin). The calculated concentrations should not be considered as exact values, but as indicators of the order of magnitude. 


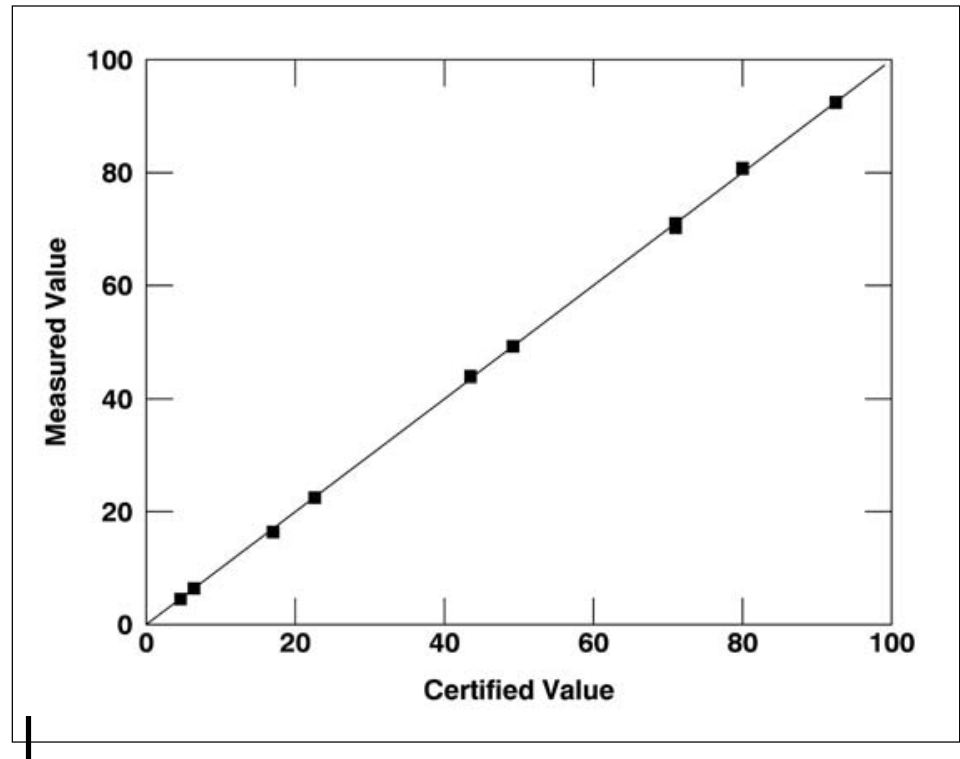

Figure 17 - The predicted and observed values, in percent, for the silver concentrations for each standard listed in table 1

The relation was calculated with Eureqa, based on the raw counts for silver, gold and copper. The $\mathrm{R}^{2}$ goodness of the fit is 0.999 , the maximum error is 0.8 and the mean squared error is 0.13

Table 2 provides the data in percent obtained for the fifteen figurines analysed in this work. The average composition was in certain cases calculated. Some data could only be obtained with difficult acquisition geometries (such as tiny narrow parts of the figurines); in these cases, we have chosen to include in the table the results obtained for the different points. We also included for two silver figurines the regions of analysis that cover a joining region, where the copper contents increase showing the use of hard-solders to make the joins. The few measurements where zinc was detected (under $0.3 \mathrm{wt} \%$, near to detection limits) correspond to tiny zones and could be considered irrelevant. Low lead, tin, and gold contents were detected only in some objects. Tin and lead are expected in silver obtained by processing silver ores by cupellation with the techniques employed from the Incan period onwards (Zori \& Tropper, 20109) and about $0.2 \mathrm{wt} \%$ gold was found

8 These two results show that the hard-solder is silver-copper alloy containing higher copper contents than the parts to be soldered to lower the melting point, but the portable equipment used in this work does not allow obtaining further data to discuss the joining technique.

9 The analysis of archaeometallurgical materials from small-scale processing of silver in the Quebrada de Tarapacá, close to Huantajaya mines in Chile, a settlement that served as the administrative centre of the lower portion of the valley in both the Late Horizon and Colonial Period until the site's abandonment in AD 1717, showed that in silver prills lead may attain about $0.8 \mathrm{wt} \%$ and tin about 0.3wt\% (Zori \& Tropper, 2010). 
Maria Filomena Guerra, Manuela Fischer, Martin Radtke, Uwe Reinholz

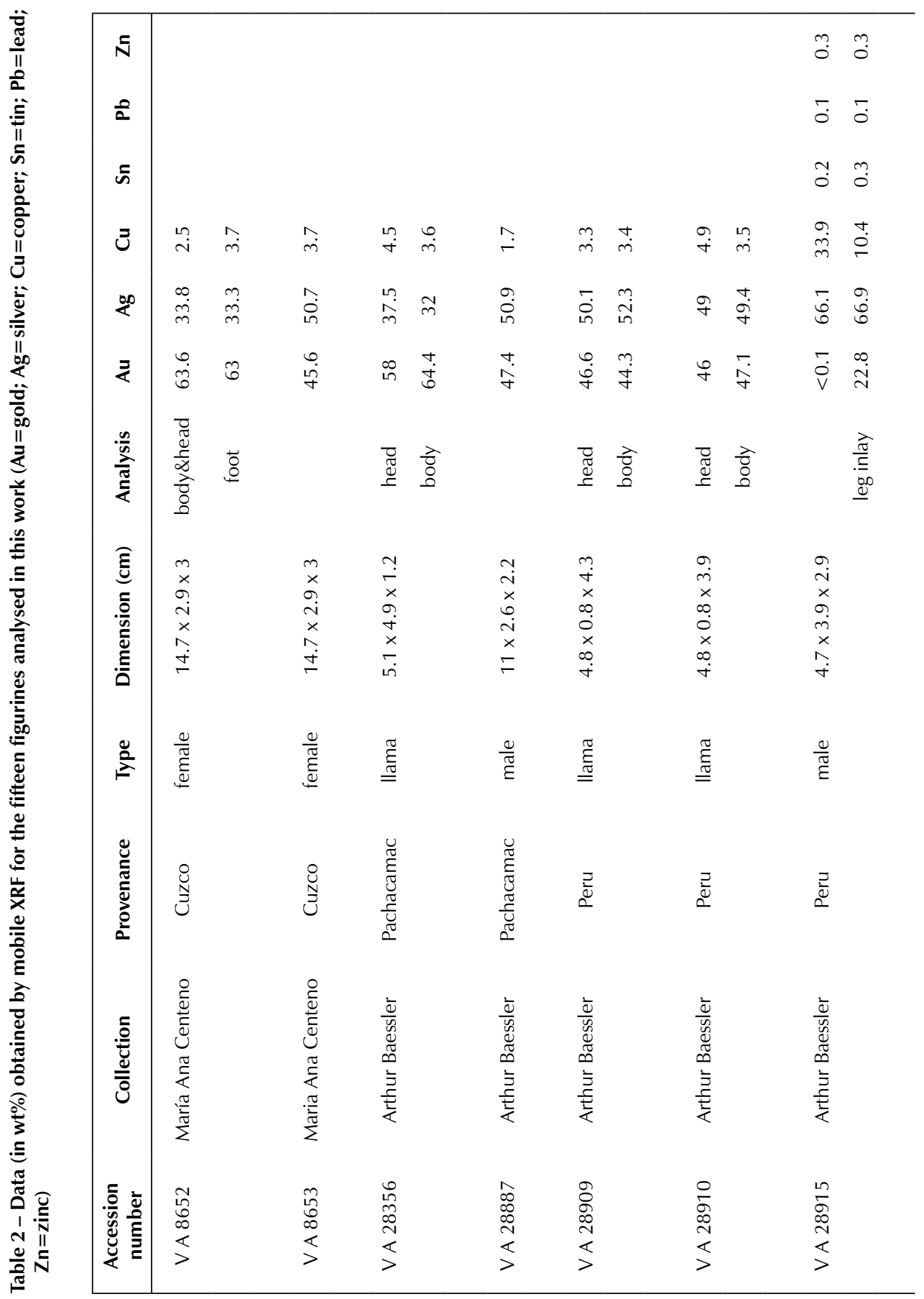


Inca figurines from the Ethnologisches Museum: an analytical study of some typical and atypical productions

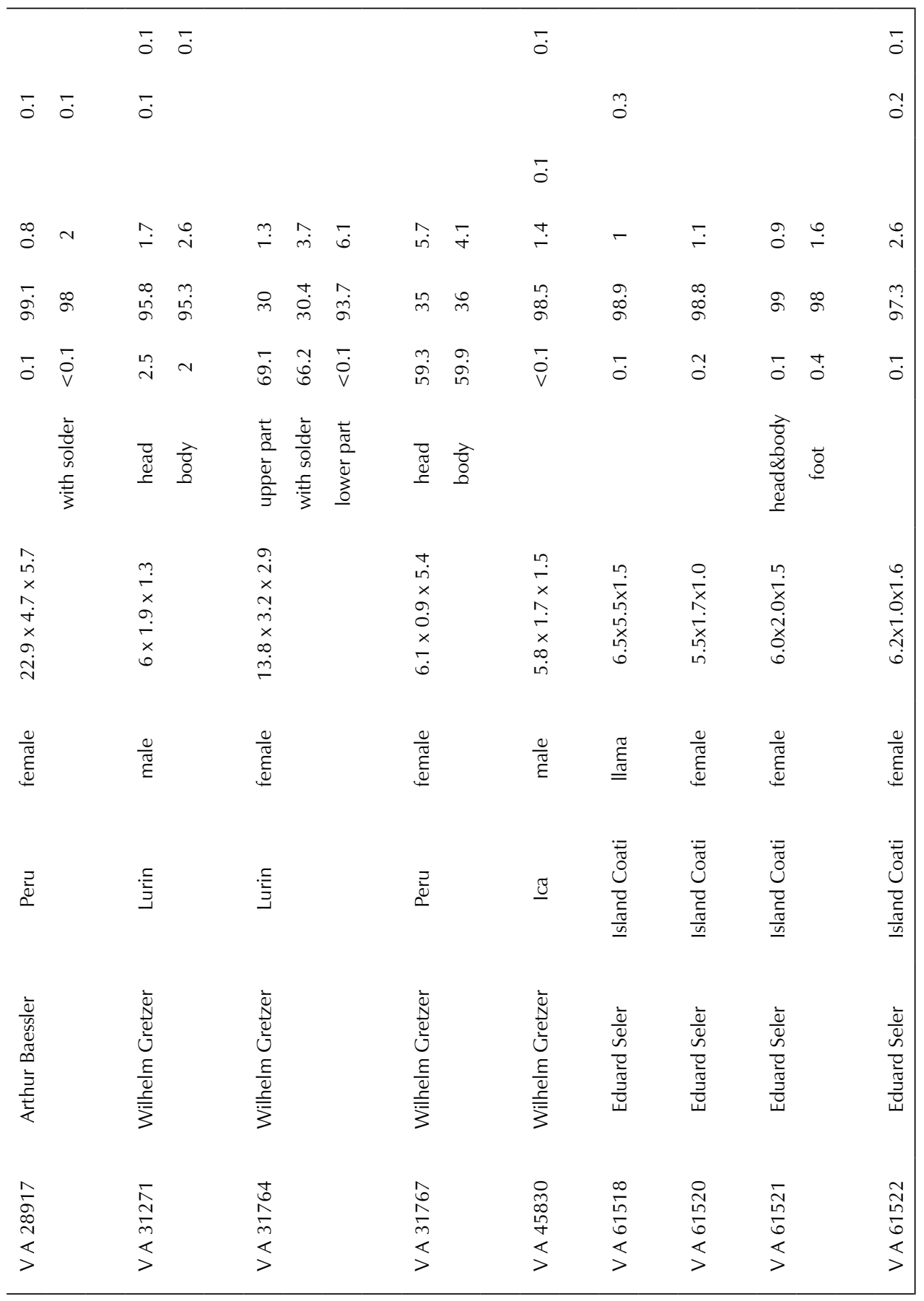


by Rivet \& Arsandaux (1946: 82) in a sample of native silver from Chuquiaguillo, Huancane, Peru.

With the exception of $\mathrm{V} A \mathrm{~A} 28915, \mathrm{~V}$ A 31761, and the lower part of bicolour figurine $V$ A 31764, all the silver figurines are made from high quality alloys containing less than $0.5 \mathrm{wt} \%$ copper. Although figurine $\mathrm{V}$ A 31761 only contains about 2.5wt\% copper and the lower part of $\mathrm{V} A 31764$ about $6 \mathrm{wt} \%$, the cast figurine $\mathrm{V}$ A 28915 with coloured inlays is made from a silver alloy of lower quality containing about $34 \mathrm{wt} \%$ copper.

To our knowledge to date only the other two silver cast figurines with inlays from Pachacamac and belonging to the Museo de América (Cuesta Domingo \& Rovira Lloréns, 1982: 198) have been fully analysed by Rovira Lloréns \& Gómez Ramos (1995). Their alloys also contain high copper contents: $29 w t \%$ and $35 w t \%$ (accession numbers 7025 and 7043, respectively). One has lost all the inlays and the other one is said to be made from silver, malachite, gold and spondyllus.

All the golden bands of the figurine V A 28915 have the same colour and texture. One of them was also analysed. Due to the large beam spot, the result is an average composition of the figurine body and the golden band. The high gold content observed $(22.8 \mathrm{wt} \%)$ proves that the band is made from gold or from a gold alloy ${ }^{10}$. We were unable to analyse with the portable XRF the blackish bands, and although gilding was used in preColumbian times to enhance the objects, the application of a silver sulphide11 does not correspond to an expected Inca technology. Due to the colours observed, none of the bands could however be from bronze, as proposed by Lapiner (1976) and Lechtman (2007) for the above-mentioned figurines from the private collection and the National Museum of Denmark. We note that the blackish bands of the figurine from the National Museum of Denmark were qualitative analysed showing the presence of malachite with a gold-silver-copper alloy, which leads Lechtman (2007: 328) to conclude that the bands could have originally be pink ${ }^{12}$.

Figurine V A 31761 shows the presence of 2-3wt\% gold in the alloy. Such gold contents in silver can be associated either to a particular silver alloy or to worn-out gilded-silver. To date, very few silver figurines from archaeological contexts have been analysed for the composition of their alloys, but none have been recorded as gilded. Furthermore, low gold content has been found in one of the silver figurines from the cacique's tomb in Paucartambo (about 2.5wt\% gold, Sierra Palomino \& Guerra, in this volume), and in the silver figurine from the shrine of Cerro

10 Based on the average data it is impossible to know whether the golden band corresponds to the use of pure gold or to the use of a gold alloy containing silver and copper.

11 Surface patination was very popular in the 19th century (Hughes, 1993), the work on the figurines surface could be a sign of a more recent production. The most commonly known inclusions in European jewellery are however made from niello, a silver-lead (sometimes copper) sulphide that when heated hardeners and becomes lustrous (for example Oddy et al., 1983).

12 The reddish colour can alternatively correspond to the use of spondylus shell insets as was found in the figurine from the site of Choquepujio (Gibaja Oviedo et al., 2014). 
Aconcagua (1.6wt\% gold, Bárcena, 2004). However, the Museum register record of the object indicates "gold foil". Further analysis will clarify this question.

Concerning the copper contents in the published silver figurines, the hollow ones of regular types belonging to the Museo de América13 (Rovira Lloréns \& Gómez Ramos, 1995) have copper contents lower than $5 \mathrm{wt} \%$. This element attains $19 \mathrm{wt} \%$ in the silver alloy employed to produce one of the cast female figurines from the tomb in Paucartambo (Sierra Palomino \& Guerra in this volume). In this tomb, a complete offering contains another cast female figurine made from a silver alloy containing $13.3 \mathrm{wt} \%$ copper. However, the remaining figurines and miniature tupus from this group are made from higher quality silver alloys; the alloys employed in the production of the two hollow specimens contain less than $2 \mathrm{wt} \%$ copper. High quality silver alloys were found for contextualised objects from two capacochas: the hollow male figurine from Cerro Aconcagua (Bárcena, 2004) is made from a silver alloy containing 2.7wt\% copper; the hollow female figurine and miniature tupu from El Plomo (Chile) analysed by Oberhauser \& Fuhrmann (1957-1959) are made from silver alloys containing 5.1wt\% and $3.6 \mathrm{wt} \%$ copper, respectively. The silver bracelet and half-moon ornament belonging both to the El Plomo's child shrine contain however higher copper contents: $19.2 \mathrm{wt} \%$ and $25.1 \mathrm{wt} \%$, respectively 14 .

With the exception of the figurine with coloured insets, figure 18 compares the data obtained for the silver figurines from the Ethnologisches Museum with the composition of published figurines of typical typology from two museums: the musée du quai Branly - Jacques Chirac (Núnez-Regueiro et al., in this volume) and the Museo de América (Rovira Lloréns \& Gómez Ramos, 1995; Rovira, in this volume). The figurines from the tomb in Paucartambo (Sierra Palomino \& Guerra, in this volume) were added to the diagram as well as the contextualised figurines from the shrines of Cerro Aconcagua (Bárcena, 2004) and El Plomo (Oberhauser \& Fuhrmann, 19571959). The prills from small-scale processing of silver in the Quebrada de Tarapacá (close to Incan Huantajaya mines in Chile15) published by Zori \& Tropper (2010) and one ingot from Tolomosa (near Tarija in Bolivia) published by Rivet \& Arsendaux (1946) were also included. In the diagram, a chemical group containing the large majority of the objects, prills and ingot can be defined. Only one cast figurine from Museo de América, two cast figurines from the tomb in Paucartambo and one prill from Quebrada de Tarapacá are not included in this group.

At this stage, with so few analytical results on the silver figurines, it seems clear that the large majority of the hollow specimens is made from a very high quality alloy that matches the composition of the silver that was sent from the mines to the capital of the empire.

Concerning the composition of the golden figurines from the Ethnologisches Museum selected for this work, table 2 shows that none of them is made from a high quality gold alloy. The silver contents range from $30 \mathrm{wt} \%$ to $52 \mathrm{wt} \%$ in the alloy,

\footnotetext{
13 Figurines selected using the online catalogue of Museo de América (when a picture was included).

14 These objects do not have the same function and could have been produced by another silversmith.

15 See note 8.
} 


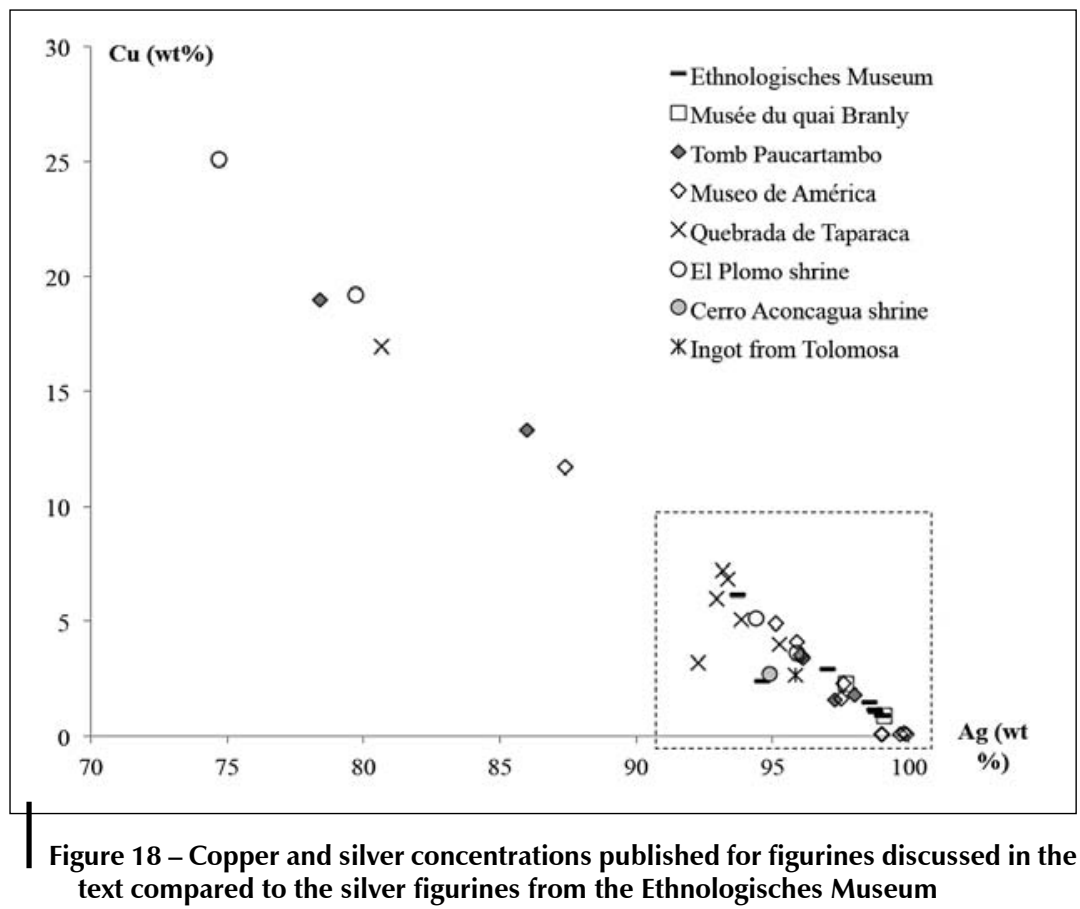

with copper contents always lower than $6 \mathrm{wt} \%$. The higher part of the bicolour figurine V A 31764 is included in the group. To date, the silver content of the gold alloys employed in the fabrication of the figurines was not fully investigated. The lone group of figurines so far analysed belongs to the Museo de América, but the objects are not contextualised. The few hollow gold figurines of regular types (see note 13) show variable compositions, with silver contents as low as about $5 \mathrm{wt} \%$ (Rovira Lloréns \& Gómez Ramos, 1995; Rovira in this volume).

The composition of a few provenanced and contextualised figurines was summarised in table 3 to be compared with our data. The lone hollow gold female figurine from the cacique's tomb in Paucartambo (Sierra Palomino \& Guerra, in this volume) is made from an alloy with high silver contents. The silver and copper contents are identical to the data obtained by the Dirección Desconcentrada de Cultura de CusCO16 for a few hollow gold anthropomorphic and zoomorphic figurines from excavations in Lucre, near Cusco. Likewise, the hollow gold male figurine from the Cerro Aconcagua shrine (Bárcena, 2004), the lone gold figurine from the El Plomo shrine (a zoomorphic hollow specimen, Oberhauser \& Fuhrmann, 1957-1959) showed high silver contents and copper contents lower than $5 \mathrm{wt} \%$. The two gold figurines from the musée du quai Branly - Jacques Chirac (Núnez-Regueiro et al.,

16 Personal communication of Dirección Desconcentrada de Cultura de Cusco to M. F. Guerra: the gold alloy contains $2-4 \mathrm{wt} \%$ copper and $35-40 \mathrm{wt} \%$ silver. 
Inca figurines from the Ethnologisches Museum: an analytical study of some typical and atypical productions

Table 3 - Elemental composition (in wt\%) of gold figurines and other gold objects in shrines and in collections published by different authors, from Museo de América, musée du quai Branly - Jacques Chirac, and Museo Inka ( $\mathrm{Au}=$ gold; $\mathrm{Ag}=$ silver; $\mathrm{Cu}=$ copper)

\begin{tabular}{|c|c|c|c|c|c|}
\hline Provenance & Publication & Type & $\mathrm{Au}$ & $\mathrm{Ag}$ & $\mathrm{Cu}$ \\
\hline El Plomo & $\begin{array}{c}\text { Oberhauser \& Fuhrmann, } \\
\text { 1957-1959 }\end{array}$ & zoomorphic & 37.8 & 43.1 & 19.1 \\
\hline \multirow[t]{4}{*}{ Cerro Aconcagua } & Bárcena, 2004 & sheet & 52.5 & 43.9 & 4.0 \\
\hline & & plaque & 51.4 & 45.8 & 3.6 \\
\hline & & zoomorphic & 68.5 & 27.5 & 4.6 \\
\hline & & anthropomorphic & 77.0 & 21.4 & 1.6 \\
\hline \multicolumn{6}{|l|}{ Museo América } \\
\hline 7399 & $\begin{array}{l}\text { Rovira Lloréns \& Gómez } \\
\text { Ramos, } 1995\end{array}$ & zoomorphic & 56.1 & 39.4 & 4.5 \\
\hline 7459 & & anthropomorphic & 92.5 & 4.67 & 2.68 \\
\hline 7460 & & anthropomorphic & 69.6 & 26.5 & 3.85 \\
\hline 7461 & & anthropomorphic & 60.2 & 34.9 & 4.87 \\
\hline 7498 & & anthropomorphic & 59.9 & 37.8 & 2.23 \\
\hline 7404 & Rovira, in this volume & zoomorphic & 53.3 & 42.4 & 4.3 \\
\hline \multicolumn{6}{|l|}{$\begin{array}{c}\text { Musée du quai } \\
\text { Branly - Jacques } \\
\text { Chirac }\end{array}$} \\
\hline 71.1887.130.2 & $\begin{array}{c}\text { Núnez-Regueiro et al., in } \\
\text { this volume }\end{array}$ & anthropomorphic & 63.4 & 35.1 & 1.5 \\
\hline \multirow[t]{2}{*}{71.1887 .130 .2} & & zoomorphic & 69.9 & 28.4 & 1.6 \\
\hline & & & 63.5 & 33.3 & 3.4 \\
\hline Paucartambo & $\begin{array}{l}\text { Sierra Palomino \& Guerra, } \\
\text { in this volume }\end{array}$ & anthropomorphic & 51.2 & 45.6 & 3.2 \\
\hline Lucre (average) & note 9 & $\begin{array}{l}\text { anthropomorphic } \\
\text { and zoomorphic }\end{array}$ & & $\begin{array}{l}35 \text { to } \\
40\end{array}$ & 2 to 4 \\
\hline
\end{tabular}


in this volume) and the remaining gold objects from the Cerro Aconcagua and the El Plomo shrines were also added to table 3.

Very few data for native gold from the Andean area (discussed for example by González, 2003) show the presence of high silver contents. Petersen (2010) cites the presence of $14.8 \mathrm{wt} \%$ silver in one sample from Peru and $26.74 \mathrm{wt} \%$ in an alluvial sample from Tumbes river also in Peru, but all the other samples that this researcher compiled have silver contents under $8.4 \mathrm{wt} \%$. The gold beads found in the Late Archaic-Early Formative period burial context at Jiskairumoko in the Lake Titicaca basin (Aldenderfer et al., 2008) also contain in average 4.3wt\% silver and $0.3 w t \%$ copper. It is however the compilation by Rivet \& Arsendaux (1946: 34-37) that provides further information on native gold in the Andean area. These samples that originate from Peru, Bolivia, Argentina17, Chile and the Colombia y Ecuador altiplano 18 were used to construct the diagram of figure 19 . This diagram shows the high variation of silver in native gold, in particular for the Colombian deposits. In spite of the very high contents attained by silver in native gold, the range of alloys employed in the fabrication of the objects from tables 2 and 3 does not match

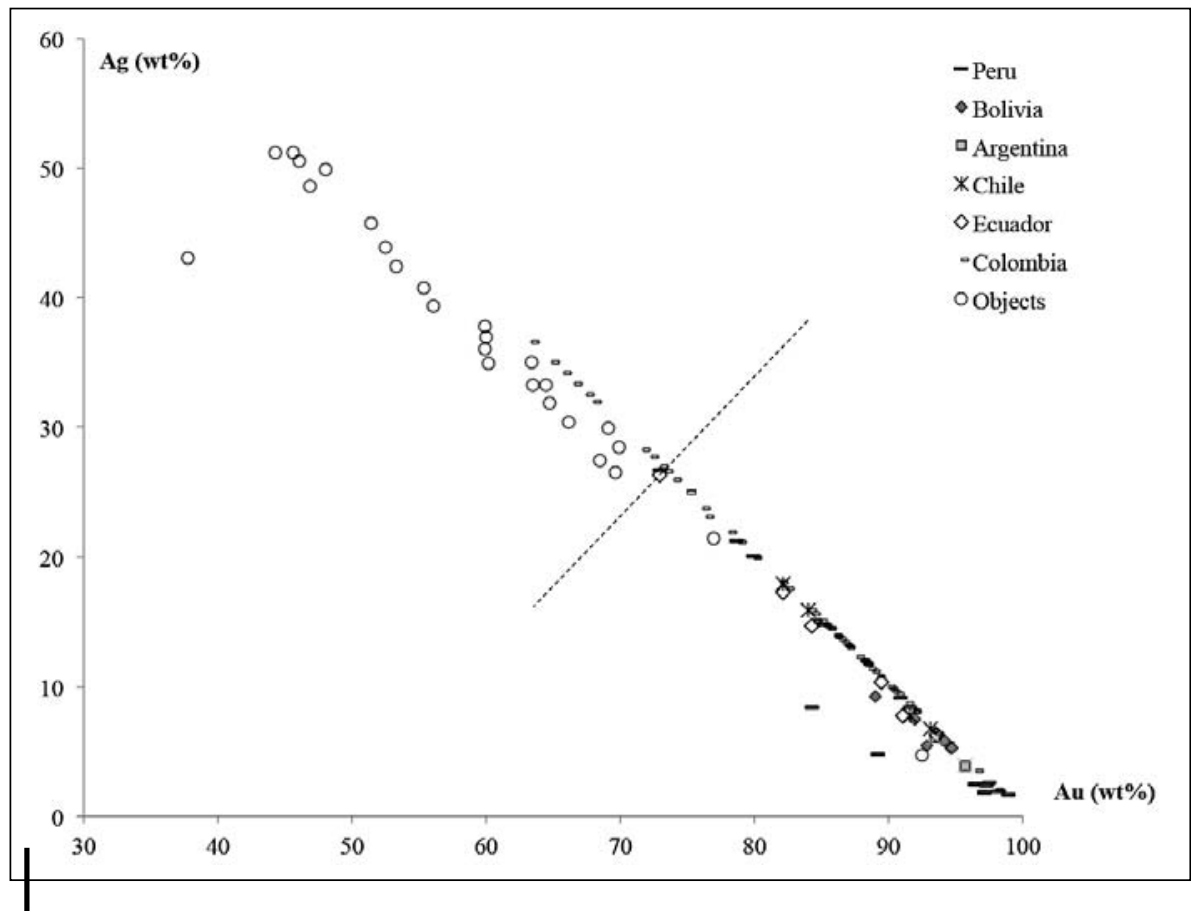

Figure 19 - Copper and silver concentration published for native gold in the Andean area from Rivet \& Arsandaux (1946) and Petersen (2010) compared with data from tables 2 and 3

17 These are the two samples published by Boman (1908).

18 We did not consider in this study those that originate from the alluvial coast deposits rich in platinum of the Esmeraldas (Ecuador) and the Cauca (Colombia) departments. 
the native gold samples. The majority of the objects are made from alloys that we consider artificial, obtained by addition of silver and copper to the native gold.

The copper contents are seldom provided for the published native samples, because this element is present at very low contents, below the detection limits of the chemical methods applied. Only two native samples from Peru show high copper contents. It is difficult to speculate given the few samples containing measurable copper contents, but the diagram of figure 20 shows that the copper contents and the ratio $\mathrm{Ag} / \mathrm{Au}$ for the native gold are different from those obtained for the objects, confirming the production of artificial alloys, presumably produced in a search for colour and texture.

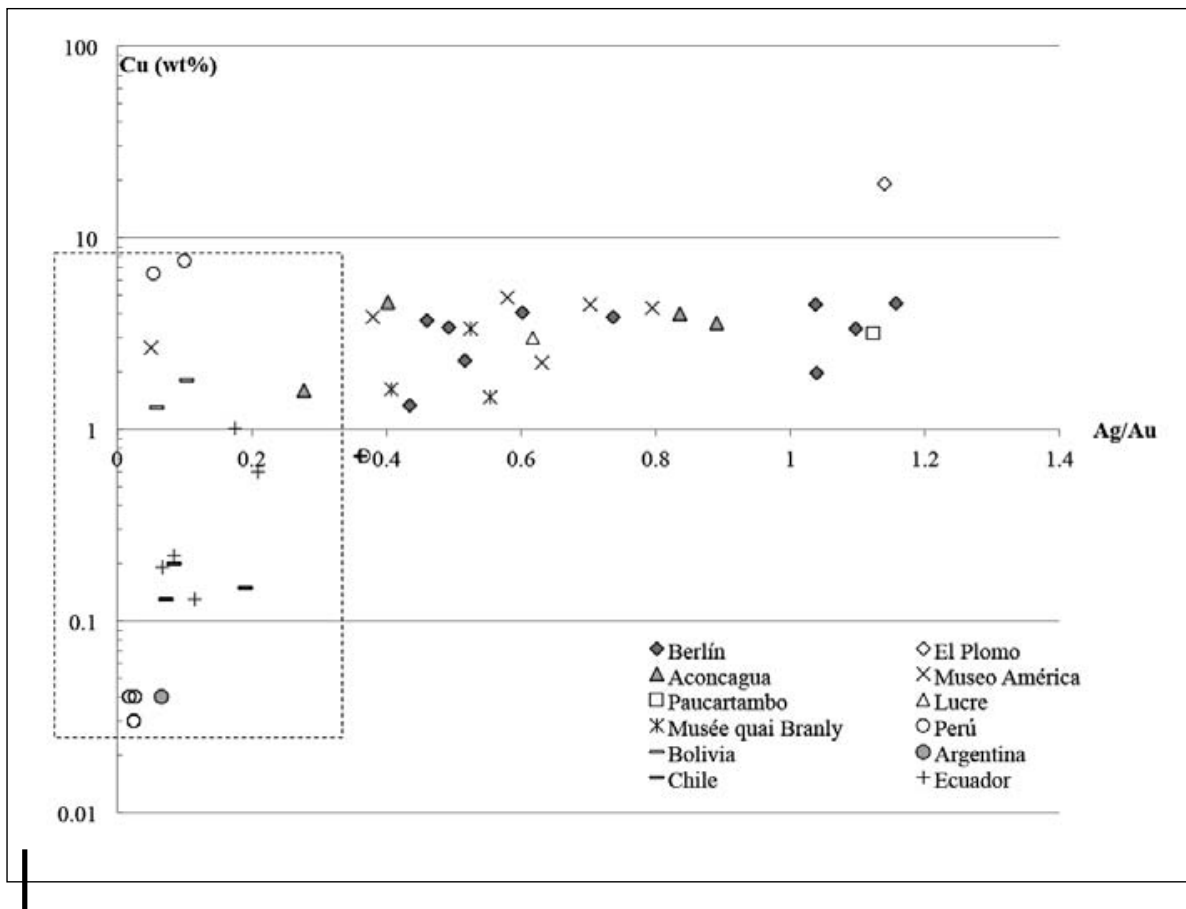

Figure 20 - Composition of native gold in the Andean area with measurable copper contents published by Rivet \& Arsandaux (1946) and Petersen (2010) compared with data from tables 2 and 3

The color of a gold alloy results from its reflectivity as a function of the frequency of the incident light. The addition of silver to gold whitens the yellow colour of gold and enhances the object surface appearance by increasing the reflectance. The reflectance of silver is close to $100 \%$ all over the visible spectra of light. In fact, when about 50wt\% silver is added to gold, the reflectivity edge of the alloy moves to the green zone of the spectrum, and when more than this amount is added, the colour moves to blue-violet (Rapson, 1990; Saeger \& Rodies, 1977; Liu et al., 2015). Copper is red-orange and its addition would change the colour of the alloy 
to other shades. The fact that all the objects analysed in this work are made from gold alloys containing between $30 \mathrm{wt} \%$ and $52 \mathrm{wt} \%$ gold and low copper contents, reveals the choice by the Incas of a particular "palette of gold", with light-yellow to green shades, to produce these ceremonial figurines. With the exception of one, all the objects from table 3 have more than 20wt $\%$ silver and low copper contents confirming the choice of this "palette of gold". One object from the Cerro Aconcagua has however a very high copper content and can be consider so far as an exception.

\section{CONCLUSIONS}

The technologies and alloys employed in the manufacture of fifteen silver and gold figurines of different typologies, from the collection of the Ethnologisches Museum in Berlin attributed to the Incas, were studied in-situ with mobile non-destructive techniques. The construction of the hollow figurines follows the regular Inca technology as well as does their chased decoration. However, the tall silver figurine V A 28917 stands out by its atypical hair, the feet made from two silver plaques instead of one plaque hammered and cut, and the nails enhanced by chasing. The lone bicolour specimen ( $\mathrm{V}$ A 31764) is made from two parts that are soldered after being fitted, contrary to the bicolour figurine from the tomb in Paucartambo.

The lone cast figurine with colour insets ( $\mathrm{V}$ A 28915) is made from a high copper silver alloy that matches the alloys published for the two identical figurines from the collection of Museo de América. The golden bands are made from gold or from a gold alloy. The other figurines are made from quite well-controlled alloys: the silver ones with alloys containing very low copper contents (less than $0.5 \mathrm{wt} \%$ for the majority) and the golden ones with alloys containing less than $6 \mathrm{wt} \%$ copper and $30-52 w t \%$ silver.

The composition of the gold alloys used in the fabrication of the figurines differ from the composition of the native gold that can be found in the Andean area, even the samples containing high silver contents. This difference is explained by the production of artificial alloys that should certainly fulfil a certain number of requirements such as the colour.

\section{Acknowledgements}

The authors would like to thank Dr. Oliver Hahn (BAM) for making available the portable XRF equipment and Dr. James Tate (National Museums Scotland) for suggestions on the manuscript. 
Inca figurines from the Ethnologisches Museum: an analytical study of some typical and atypical productions

\section{Cited references}

ALDENDERFER, M., CRAIG, N. M., SPEAKMAN, R. J. \& POPELKA-FILCOFF, R., 2008 Four-thousand-year-old gold artifacts from the Lake Titicaca basin, southern Peru. Proceedings of the National Academy of Sciences, 105 (13): 5002-5005.

BAESSLER, A., 1906 - Altperuanische Metallgeräte: nach seinen Sammlungen, 137 pp.; Berlín: Verlag von Georg Reimer.

BÁRCENA, J. R., 2004 - Las piezas metálicas de la ofrenda ritual del Cerro Aconcagua. Mendoza, República Argentina. In: Tecnología del oro antiguo: Europa y América (A. Perea, I. Montero Ruiz \& Ó. García Vuelta, eds.): 157-172; Madrid: Consejo Superior de Investigaciones Científicas.

BENSON, E., 2001 - Why Sacrifice? In: Ritual Sacrifice in Ancient Peru (E. P. Benson \& A. G. Cook, eds.): 1-20; Austin: University of Texas.

BESOM, T., 2013 - Inka Human Sacrifice and Mountain Worship: Strategies for Empire Unification, 330 pp.; Albuquerque: University of New Mexico Press.

BOMAN, E., 1908 - Antiquités de la région andine de la République Argentine et du désert Atacama, 948 pp.; Paris: Imprimerie Nationale.

BRAY, W., 1993 - Techniques of gilding and surface enrichment in pre-Hispanic American metallurgy. In: Metal plating and patination: cultural, technical and historical developments (S. La Niece \& P. Craddock, eds.): 182-192: Oxford: Butterworth Heinemann.

CUESTA DOMINGO, M. \& ROVIRA LLORÉNS, S., 1982 - Los trabajos en metal en el área andina, 258 pp.; Madrid: Museo de América, Ministerio de Cultura.

DRANSART, P., 1995 - Elemental meanings: Symbolic expression in Inka miniature figurines, 58 pp.; London: Institute of Latin American Studies, University of London.

DRANSART, P., 2000 - Clothed metal and the iconography of human form among the Incas. In: Precolumbian gold: technology, style and iconography (C. McEwan, ed.): 76-91; London: British Museum Press.

FERNÁNDEZ MURILLO, M. S., 2015 - Prendedores, topos y mujeres, 204 pp.; La Paz: Museo Nacional de Etnografía y Folklore-Musef.

FISCHER, M., 2015 - The Inca collection at the Ethnologisches Museum Berlin. Genesis and contexts. Tribus, 293: 25-37.

GIBAJA OVIEDO, A. M., McEWAN, G. F., CHATFIELD, M. \& ANDRUSHKO, V., 2014 Informe de las posibles capacochas del asentamiento arqueológico de Choquepujio, Cusco, Perú. Nawpa Pacha. Journal of Andean Archaeology, 34 (2): 147-175.

GONZÁLEZ, L. R., 2003 - El oro en el noroeste argentino prehispánico. Estudios técnicos sobre dos objetos de la Casa Morada de La Paya. Relaciones de la Sociedad Argentina de Antropología, 28: 75-99.

GUERRA, M. F., 2008 - An overview on the ancient goldsmith's skill and the circulation of gold in the past: the role of X-ray based techniques. X-ray Spectrometry, 37 (4): 317-327.

GUERRA, M. F., 2009 - Gold studies. In: A quest for authenticity (M. L. Vitobello \& T. Rehren, eds.): 89-103; London: Institute for Archaeo-Metallurgical Studies (IAMS), UCL Institute of Archaeology.

GUERRA, M. F. \& TISSOT, I., 2016 - Bronze Age and Iron Age gold torcs and earrings from the Iberian Atlantic façade: a non-invasive multi-analytical approach to the characterisation of the alloys and the corrosion. X-ray Spectrometry, 45 (1): 5-13. 
HUGHES, R., 1993 - Artificial patination. In: Metal plating and patination: cultural, technical and historical developments (S. La Niece \& P. Craddock, eds.): 1-18; Oxford: Butterworth-Heinemann.

IDIENS, D., 1971 - Ancient American Art, 40 pp.; Edinburgh: Royal Scottish Museum.

LAPINER, A., 1976 - Pre-Columbian Art of South America, 460 pp.; New York: Harry N. Abrams, Inc.

LECHTMAN, H., 1973 - The gilding of metals in pre-Columbian Peru. In: Application of Science in Examination of Works of Art (W. J. Young, ed.): 38-52; Boston: Museum of Fine Arts.

LECHTMAN, H., 2007 - The Inka and Andean metallurgical tradition. In: Variations in the expression of Inka power (R. L. Burger, C. Morris, \& Matos Mendieta, eds.): 313355; Washington, D. C.: Dumbarton Oaks.

LECHTMAN, H., 2014 - Andean metallurgy in Prehistory. In: Archaeometallurgy in Global Perspective (B. W. Roberts \& C. Thornton, eds.): 361-422; New York: SpringerVerlag.

LIU, J., LIU, Y., GONG, P., LI, Y., MOORE, K., SCANLEY, E., WALKER, F., BROADBRIDGE, C. \& SCHROERS, J., 2015 - Combinatorial exploration of color in gold-based alloys. Gold Bulletin, 48 (3): 111-118.

McEWAN, C., 2015 - Ordering the sacred and recreating Cuzco. In: The archaeology of Wak'as: explorations of the sacred in the Pre-Columbian Andes (T. L. Bray, ed.): 265291; Boulder: University Press of Colorado.

MIGNONE, P., 2015 - Illas y allicac. La capacocha del Llullaillaco y los mecanismos de ascenso social de los "inkas de privilegio". Boletín del Museo Chileno de Arte Precolombino, 20 (2): 69-87.

OBERHAUSER, F. \& FUHRMANN, P., 1957-1959 - Estudio metalúrgico. In: La momia del Cerro El Plomo (G. Mostny, ed.): 78-81; Santiago de Chile: Boletín del Museo Nacional de Historia Natural, vol. 27.

ODDY, W. A., BIMSON, M. \& LA NIECE, S., 1983 - The Composition of Niello Decoration on Gold, Silver and Bronze in the Antique and Mediaeval Periods. Studies in Conservation, 28 (1): 29-35.

PETERSEN, G., 2010 - Mining and metallurgy in ancient Perú, 90 pp.; Colorado: Geological Society of America, special paper 467, translated by W. E. Brooks.

RAPSON, W.S., 1990 - The metallurgy of the coloured carat gold alloys. Gold Bulletin, 23 (4): 125-133.

REINHARD, J., 1992 - Underwater archaeological research in Lake Titicaca, Bolivia. In: Ancient America: Contributions to New World Archaeology (N. Saunders, ed.): 117143; Oxford: Oxbow books.

REINHARD, J. \& CERUTI, C., 2005 - Sacred Mountains, Ceremonial Sites, and Human Sacrifice Among the Incas. Archaeoastronomy, 19: 1-43.

RIVERO, M. E. de \& TSCHUDI, J. D. von, 1851 - Antigüedades peruanas, 328 pp.; Viena: Imprenta Imperial de la Corte y del Estado.

RIVET, P. \& ARSANDAUX H., 1946 - La métallurgie en Amérique précolombienne, 258 pp.; Paris: Institut d'Ethnologie.

ROVIRA LLORÉNS, S. \& GÓMEZ RAMOS, P., 1995 - Los objetos de metal de la colección Juan Larrea: un estudio arqueometalúrgico. Anales del Museo de América, 3: 21-33.

ROWE, J. H., 1996 - Inca. In: Andean Art at Dumbarton Oaks (E. Hill Boon, ed.): 301-320; Washington, D. C.: Dumbarton Oaks Research Library and Collection. 
Inca figurines from the Ethnologisches Museum: an analytical study of some typical and atypical productions

SAEGER, K. E. \& RODIES, J., 1977 - The colour of gold and its alloys. The mechanism of variation in optical properties. Gold Bulletin, 10 (1): 10-14.

SCHMIDT, M. \& LIPSON, H., 2009 - Distilling free-form natural laws from experimental data. Science, 324 (5923): 81-85.

SCHULER-SCHÖMIG, I. von, 1981 - Werke indianischer Goldschmiedekunst, 43 pp.; Berlin: Staatliche Museen, Preußischer Kulturbesitz.

VALENCIA, A., 1981 - Metalurgia Inca, 93 pp.; Lima: Dirección Universitaria de Proyección, San Marcos.

VETTER, L., 2007 - La evolución del Tupu en forma y manufactura desde los Incas hasta el siglo XIX. In: Metalurgia en la América antigua. Teoría, arqueología y tecnología de los metales prehispánicos (R. Lleras Pérez, ed.): 101-128; Lima: Instituto Francés de Estudios Andinos, Fundación de Investigaciones Arqueológicas Nacionales-Banco de la República.

ZORI, C. M. \& TROPPER, P., 2010 - Late Pre-Hispanic and Early Colonial silver production in the Quebrada de Tarapacá, Northern Chile. Boletín del Museo Chileno de Arte Precolombino, 15 (2): 65-87. 